\title{
Anticancer activity of Nigerian medicinal plants: a review
}

\author{
Franklyn O. Ohiagu' ${ }^{1}$, Paul C. Chikezie ${ }^{1 *}(\mathbb{D})$ Chinwendu M. Chikezie ${ }^{2}$ (D) and Christian E. Enyoh ${ }^{3}$ (D)
}

\begin{abstract}
Background: Cancer is currently the leading cause of death globally and the number of deaths from cancer is on the rise daily. Medicinal plants have been in continuous use over the years for the management of cancer, particularly, in most developing countries of the world including Nigeria. The use of synthetic drugs for the treatment of cancer is often accompanied by toxic side effects. Thus, the alternative use of readily available and inexpensive medicinal plants is the panacea to the toxic side effects associated with synthetic drugs.

Main body: The present review summarized the anticancer activity of 51 medicinal plants that are widespread in all regions of Nigeria. Furthermore, the proposed anticancer pharmacological actions as well as the anticancer bioactive compounds, the type of cancer cell inhibited, the plant parts responsible for the anticancer activity, and the nature of the extracts used for the studies were discussed in this review. The 51 Nigerian medicinal plants were reported to exhibit anticancer activities of the prostate, cervices, lung, skin, colon, esophagus, blood, ovary, central nervous system/brain, breast, stomach, pancreas, larynx, and kidney. The major classes of bioactive compounds indicated to be responsible for the anticancer activity include the polyphenols, flavonoids, alkaloids, saponins, triterpenes, tannins, and quinones. The major anticancer pharmacological actions of these bioactive compounds were antiproliferative, cytotoxic, cytostatic, antimetastatic, apoptotic, and antioxidative as well as provoked cell cycle arrest, inhibition of angiogenesis and reduction of cancer cell viability.

Conclusion: The Nigerian medicinal plants can be harnessed to provide for readily available and inexpensive anticancer drugs in the future because the plants reported in this review showed promising anticancer activity.

Keywords: Nigeria, Medicinal plants, Anticancer, Antiproliferative, Cytotoxic, Apoptotic
\end{abstract}

\section{Background}

Cancer is currently the leading cause of death globally [1] and the number of deaths from cancer is on the rise daily. The number of recorded deaths of persons as a result of cancer rose by 17\% between 2005 and 2015, and therefore, there is the urgent need for more intensive research into the development of new anticancer drugs in addition to the existing ones [2]. Cancer is a disease that is characterized by proliferation of the body cells, due to failures in cellular modulation and obstruction of cell cycle progression, and thereby eliciting malignant tumor

\footnotetext{
* Correspondence: p_chikezie@yahoo.com

${ }^{1}$ Department of Biochemistry, Imo State University, Owerri, Nigeria

Full list of author information is available at the end of the article
}

cells formation with the possibility of becoming metastatic [3].

Plant extracts are widely used in Nigeria as important sources of chemotherapeutic agents in spite of the use of synthetic drug by vast majority of the populace. Medicinal plants have been in continuous use over the years for the management of cancer [4], particularly, in most developing countries of the world including Nigeria. The use of synthetic drugs for the treatment of cancer is often accompanied by toxic side effects. Thus, the alternative use of readily available and inexpensive medicinal plants is the panacea to the toxic side effects associated with synthetic drugs [5]. These medicinal plants are made up of bioactive compounds that are responsible for their pharmacological actions in the human body. 
Clinical studies and phytochemical screening have established the antitumor activity of herbal remedies against different types of cancers [6-11].

Notwithstanding the fact that many anticancer agents have been derived from medicinal plants, many plants with anticancer potentials are yet to be discovered. There are over 114,000 plant extracts that are being analyzed for their anticancer activity in various cancer institutes. Accordingly, there is a pressing need to carry out conclusive investigations to establish whether these extracts exhibit anticancer activity and applied as chemotherapeutic agents $[12,13]$.

One of the major approaches towards new drug discovery is applying the knowledge of ethnobotanical properties of medicinal plants; the so-called ethnobotanical bioprospecting [14-18]. This common approach, which is based on specific traditional uses of herbs in Nigeria, depends majorly on the extent at which the herb was able to cure a particular disease among the populace. Ethnomedicinal practices are usually transferred from one generation to another, and thus, serve as an effective and reliable guide towards the identification of plants that exhibit anticancer activity.

The present review summarized the anticancer activity of Nigerian medicinal plants that have been empirically investigated. The review also highlighted the plant parts and bioactive compounds responsible for the anticancer activity as well as their possible pharmacological actions.

\section{Main text}

\section{Information and data acquisition}

The information and data used in this review were sourced from scientific databases such as Google Scholar, PubMed, SpringerLink, Medline, ScienceDirect, and Mendeley. Publications from 1972 to 2020 were retrieved from these scientific search engines giving rise to 254 references that were cited in this report.

\section{The Nigerian medicinal plants with promising anticancer activity}

This review highlighted 51 anticancer medicinal plants that are widespread in all regions of Nigeria. Furthermore, the proposed anticancer pharmacological actions as well as the anticancer bioactive compounds, the type of cancer cell inhibited, the plant parts responsible for the anticancer activity, and the nature of the extracts used for the studies were reported and are summarized in Table 1.

\section{Acronychia baueri (Rutaceae)}

The aqueous bark extract of $A$. baueri has been reported to exhibit remarkable antitumor activity. The antitumor activity of the bark of $A$. baueri was due to the presence of alkaloids (normelicopidine, melicopine, acronycine) and triterpene lupeol, whereby acronycine exhibited the highest antitumor activity [19].

\section{Ageratum conyzoides (Compositae)}

The cytotoxicity of ethylacetate extract of $A$. conyzoides on A549 (lung carcinoma) and P388 (leukemia) cell lines in humans and mouse, respectively, has been reported [20]. The leaf extract of $A$. conyzoides also inhibited the proliferation of SF-767, LNCaP, PC-3, and SF-763 cancer cell lines [21]. The anticancer effect of the leaf extract of A. conyzoides was reported to be as a result of the presence of the anticancer compounds: kaempferol, oxygenated terpenes, sesquiterpene hydrocarbons, and monoterpene hydrocarbons [20, 21].

\section{Alchornea cordifolia (Euphorbiaceae)}

The methanolic leaf extract of $A$. cordifolia initiated cell death through the activation of caspases, damage of the mitochondrial membrane, and stimulation of reactive oxygen species (ROS) generation in adriamycin-sensitive leukemia (CCRF-CEM cells). The methanolic bark extract of $A$. cordifolia was also reported to have deleterious effects on CCRF-CEM cells [22]. The bioactive compounds isolated from A. cordifolia with possible anticancer potentials include the flavonoids, saponins, cardiac glycosides, steroids, anthraquinone, terpenes, xanthones, alkaloids, and tannins [23].

\section{Allium sativum (Amaryllidaceae)}

A. sativum L., also known as garlic, is a rich source of Sallylcysteine and S-allylmercapto-L-cysteine. These bioactive compounds are known to exhibit high radical scavenging activity, which is essential in the inhibition of cancer development. S-allylcysteine also retarded tumor growth [24]. Additionally, A. sativum repressed the proliferations of skin, colon, lung, prostate, leukemia, and breast cancer cells in vitro $[25,26]$.

\section{Aloe barbadensis (Asphodelaceae)}

Ethanol extract of $A$. barbadensis (Aloe vera) exhibited antitumor activities through the modulation of lipid peroxidation and stimulation of the antioxidant defense system in mice $[27,28]$. The anticancer activity of $A$. barbadensis was attributed to aloe-emodin, which was identified in leaf extract of the plant. This bioactive compound exhibited cytotoxicity in hepatoma cell and neuroectodermal tumors, as well as lung squamous cell carcinoma [27]. The cytotoxicity of $A$. barbadensis against HepG2 and HCC cancer cell lines has also been reported [28].

\section{Alstonia boonei (Apocynaceae)}

The methanol and $n$-hexane stem-bark extracts of $A$. boonei have been established to be cytotoxic to cancer 


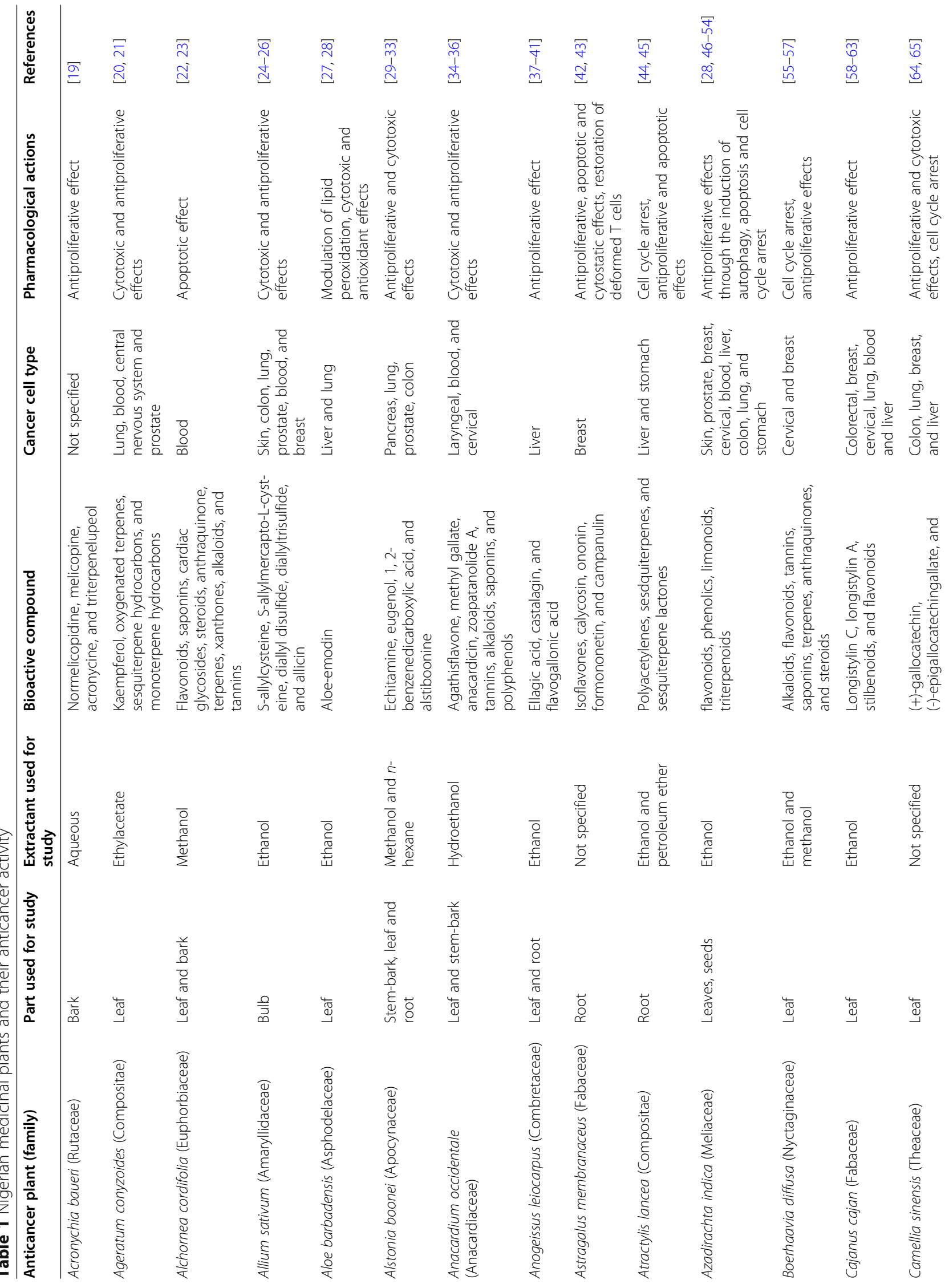




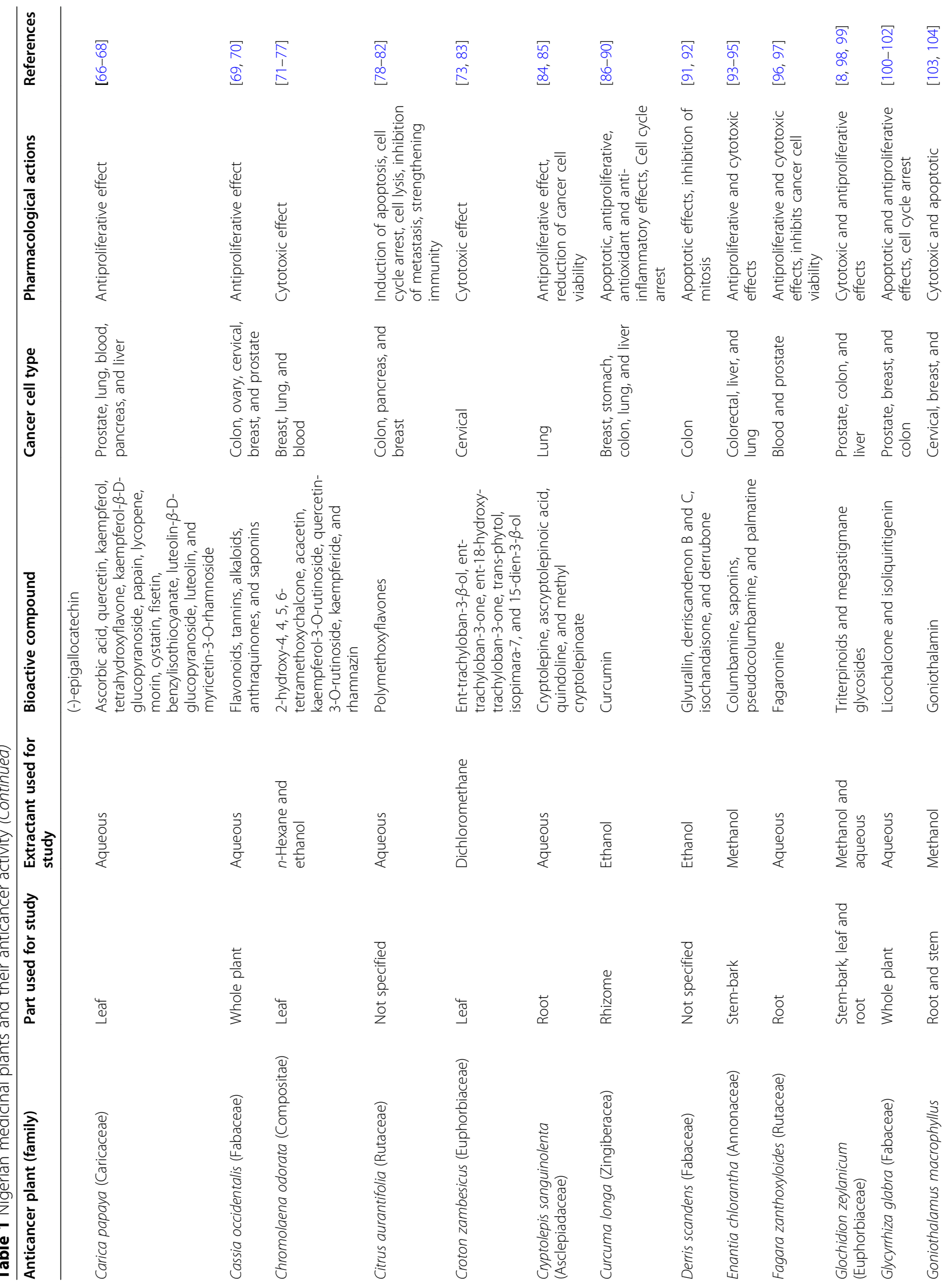




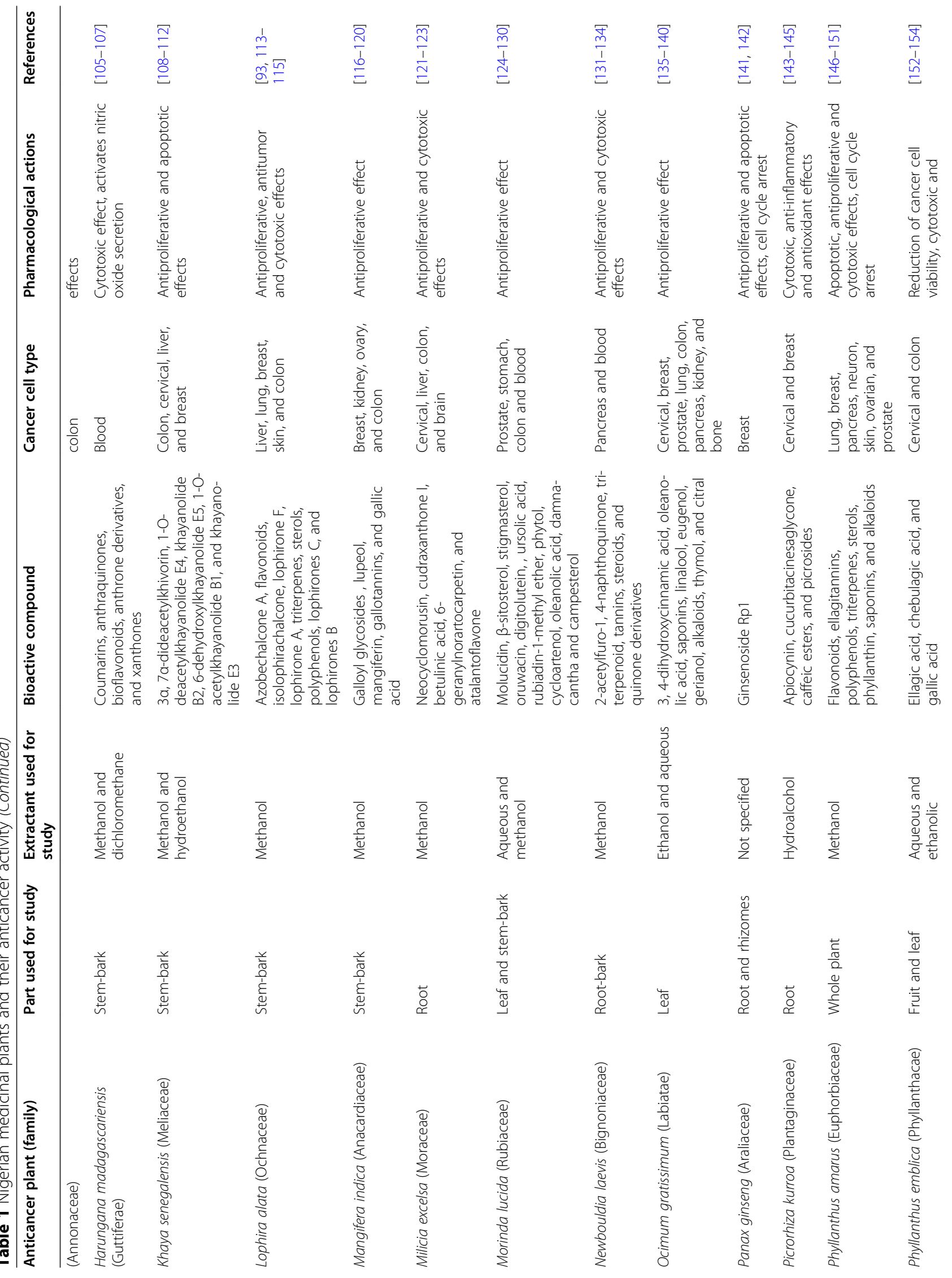




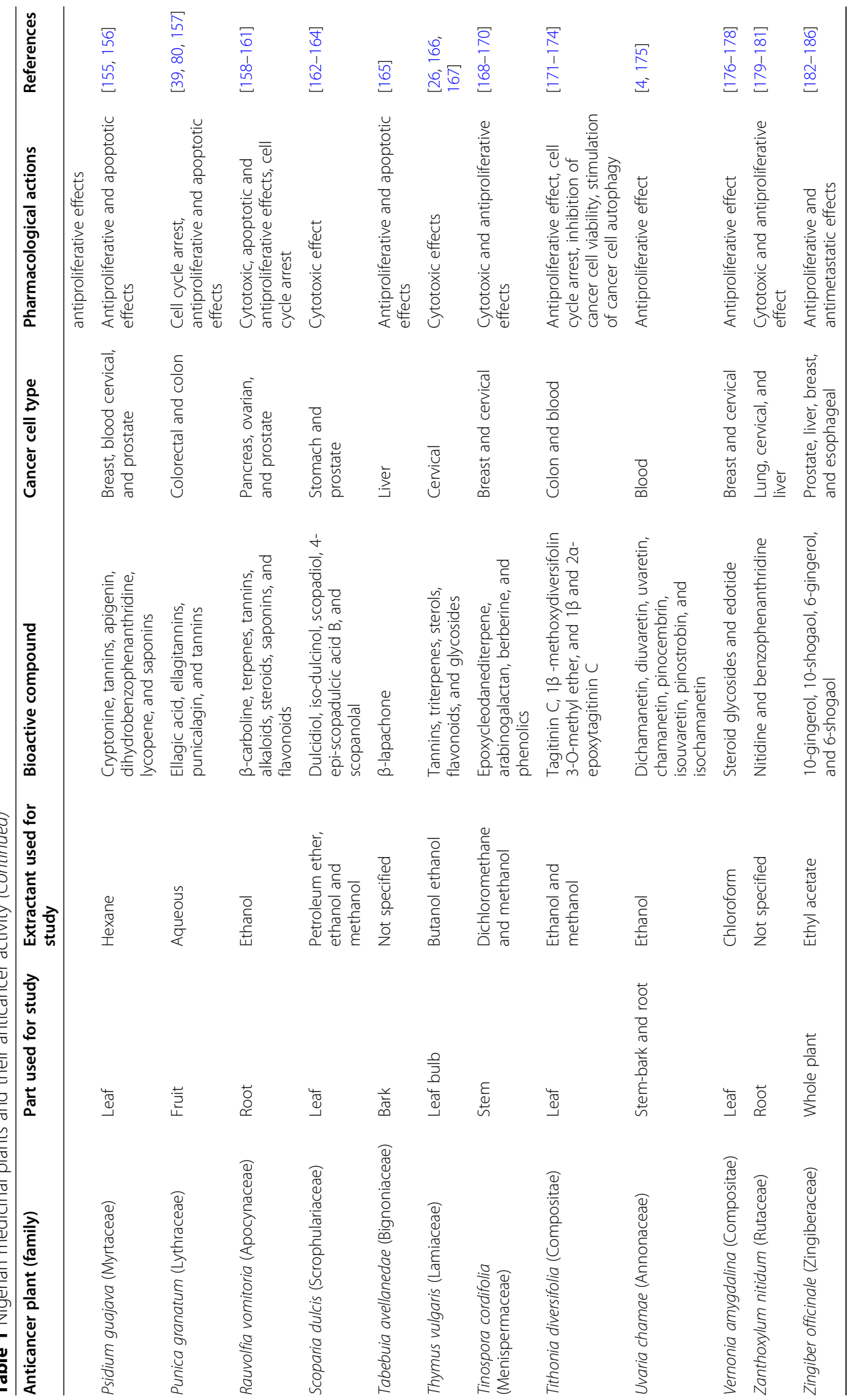


cells [29]. The bioactive compound, echitamine, present in the stem-bark of $A$. boonei hindered the development and caused the extermination of fibrosarcoma in rat models [30]. Two bioactive compounds, namely, eugenol and 1, 2-benzenedicarboxylic acid isolated from the leaf and root, respectively, of $A$. boonei suppressed the proliferation of $\mathrm{MiaPaCa}$ (pancreas), A549 (lung), PC-3 (prostate), and HCT-116 (colon) cancer cell lines [31-33]. Alstiboonine is another bioactive compound from stembark of $A$. boonei that has been noted to exhibit deleterious effects on cancer cells [29].

\section{Anacardium occidentale (Anacardiaceae)}

Hydroethanolic leaf extract of $A$. occidentale has shown cytotoxicity against leukemia cells. The leaf of this medicinal plant inhibited the proliferation of leukemic cancer cells and was slightly cytotoxic to the cell lines: Hep-2 (laryngeal cancer), HL-60 (leukemia), and Raji (Burkitt lymphoma). These anticancer activities were attributed to the presence of agathisflavone in the hydroethanolic leaf extract of $A$. occidentale [34]. According to Taiwo et al. [35], methyl gallate, anacardicin, zoapatanolide A, and agathisflavone exhibited cytotoxicity against HeLa (cervical cancer) cells. Furthermore, Obembe and Ige [36] noted that the stem-bark and leaves of A. occidentale are rich sources of the anticancer compounds such as tannins, alkaloids, saponins and polyphenols.

\section{Anogeissus leiocarpus (Combretaceae)}

The inhibition of cancer cell proliferation by leaf and root extracts of $A$. leiocarpus have been reported by Olugbami et al. [37] and Salau et al. [38], respectively. The ethanolic leaf extract of $A$. leiocarpus hindered the proliferation of liver carcinoma HepG2 cell lines [37], whereas the root extract hindered Ehrlich ascites carcinoma cell lines [38]. Ellagic acid, castalagin, and flavogallonic acid are bioactive compounds known for their cancer cell proliferation inhibitory activity and have been isolated from A. leiocarpus [39-41].

\section{Astragalus membranaceus (Fabaceae)}

Root extract of A. membranaceus exhibited antitumor activity in vitro and in vivo through its cytostatic activity in myeloid and macrophage-like tumors. This plant also repressed syngeneic tumor development. The potency of root extracts of $A$. membranaceus to restore the functionality of $\mathrm{T}$ cells in cancer patients has been ascertained and reported [42]. A. membranaceus inhibited the proliferation and induced the apoptosis of breast cancer cell lines (MDA-MB-231, MCF-7, and SK-BR-3). The bioactive compounds, namely, isoflavones, calycosin, ononin, formononetin, and campanulin, have been isolated from A. membranaceus and established to be potent anticancer agents [43].

\section{Atractylis lancea (Compositae)}

The ethanol extract of $A$. lancea inhibited the proliferation of Hep-G2 liver cancer cell lines in vitro and induced apoptosis through the restriction of G1-phase cell cycle, disruption of mRNA, and protein synthesis, and thereby retarded telomerase action [44]. The petroleum ether root extract of $A$. lancea was reported to inhibit the growth of gastric cancer cell lines (SGC-7901 and BGC-823) through the blockage of the cell cycle and apoptosis. Polyacetylenes, sesquiterpenes, and sesquiterpene lactones are the major bioactive compounds from petroleum ether root extract of $A$. lancea with potential anticancer activity [45].

\section{Azadirachta indica (Meliaceae)}

Leaf and seed extracts of $A$. indica inhibited the proliferation of cancer cells as well as induced the death of cancer cells by autophagy and apoptosis. The inhibition of cancer cell proliferation was achieved and sustained by $A$. indica through obstruction of cell cycle progression $[28,46,47]$. The leaf and seed extracts of $A$. indica stimulated the apoptosis of leukemia, colon, breast, cervical, hepatocarcinoma, choriocarcinoma, stomach, and prostate cancer cells [48, 49, 100,187-189]. The seed oil of A. indica inhibited the proliferation of HeLa cervical and prostate cancer cells $[50,51]$. The major classes of bioactive compounds responsible for the anticancer activity of $A$. indica include the flavonoids, phenolics, limonoids, and triterpenoids. The ethanolic leaf extract of $A$. indica repressed the development of PC-3M-luc2 and C4-2B prostate cancer cells in vitro [52]. Generally, A. indica has been effective in the repression of skin, prostate, breast, cervical, leukemia, liver, colon, lung and stomach cancers $[53,54]$.

\section{Boerhaavia diffusa (Nyctaginaceae)}

The ethanolic extract of $B$. diffusa has been reported to block the cell cycle at the S-phase as well as destroy HeLa cell lines. B. diffusa also hindered the proliferation of cancer cells in mice through free radical scavenging activity [55]. The cytotoxic activity of the methanolic leaf extract of $B$. diffusa against breast cancer (MCF-7) cell lines was established by Muthulingam and Chaithanya [56]. Alkaloids, flavonoids, tannins, saponins, terpenes, anthraquinones, and steroids have been identified to be present in $B$. diffusa extract and are considered to be responsible for the anticancer activity of the plant [57].

\section{Cajanus cajan (Fabaceae)}

The ethanolic leaf extract of $C$. cajan repressed CaCo-2 (colorectal), MCF-7 (breast), and HeLa (cervical) cancer cell lines [58]. The bioactive compounds, longistylin C, and longistylin A, from C. cajan inhibited the proliferation of A549 (lung), CCRF-CEM, Ehrlich's ascites 
carcinoma, and HepG2 cancer cell lines [59-61]. Other bioactive compounds from C. cajan with promising anticancer activity include the stilbenoids and flavonoids [62, 63].

\section{Camellia sinensis (Theaceae)}

The leaf extracts of $C$. sinensis exhibited antitumor activity against human HT-29 colon carcinoma, UACC-375 melanoma, MCF-7 breast carcinoma, and A-427 lung carcinoma owing to the presence of the following bioactive compounds: (+)-gallocatechin, (-)-epigallocatechin-3-gallate, and (-)-epigallocatechin [64]. The potency of (-)-epigallocatechin-3-gallate present in $C$. sinensis to induce cell cycle arrest and inhibit the development of cancer cells (hepatocellular carcinoma) has been ascertained and reported [65].

\section{Carica papaya (Caricaceae)}

The efficacy of leaf extracts of C. papaya in the treatment of prostate cancer has been reported [66]. The aqueous leaf extract of $C$. papaya effectively suppressed the proliferation of plasma cell leukemia (ARH77 cell line), lung cancer (PC14 cell line), pancreatic adenocarcinoma (Capan1 cell line), Burkitt's lymphoma (K562 cell line), pancreatic carcinoma (Panc-1 cell line), large cell lymphoma (Karpas-299 cell line), mesothelioma (JMN cell line), and hepatocellular carcinoma (Huh7 cell line) [67]. Certain bioactive compounds that have been isolated from $C$. papaya leaves are considered to be likely responsible for the anticancer acitivity. These bioactive compounds include ascorbic acid, quercetin, kaempferol, tetrahydroxyflavone, kaempferol- $\beta$-D-glucopyranoside, papain, lycopene, morin, cystatin, fisetin, benzylisothiocyanate, luteolin- $\beta$-D-glucopyranoside, luteolin, and myricetin-3-O-rhamnoside $[67,68]$.

\section{Cassia occidentalis (Fabaceae)}

The study done by Bhagat and Saxena [69] elucidated the anticancer activity of aqueous extract of C. occidentalis. According to the study by Bhagat and Saxena [69], aqueous extract of $C$. occidentalis inhibited the proliferation of SW-620 (colon cancer), HCT-15 (colon cancer), OVCAR-5 (ovarian cancer), SiHa (cervical cancer), MCF-7 (breast cancer), and PC-3 (prostate cancer) cell lines. However, Bhagat and Saxena [69] did not isolate and identify the specific bioactive compounds responsible for the anticancer efficacy of aqueous extract of $C$. occidentalis. Nevertheless, in general terms, the anticancer activity of $C$. occidentalis have been linked to the presence of the following classes of bioactive compounds isolated from C. occidentalis: the flavonoids, tannins, alkaloids, anthraquinones, and saponins [70].

\section{Chromolaena odorata (Compositae)}

The $n$-hexane leaf extract of $C$. odorata suppressed MCF7, MDAMB-468, and CAL51 breast cancer cell lines, whereas the ethanolic leaf extract repressed Lewis lung carcinoma cell (LLC) and HL-60 human leukemia cell lines. The 2-hydroxy-4, 4, 5, 6-tetramethoxychalcone isolated from $n$-hexane leaf extract of $C$. odorata was noted to be responsible for its anticancer activity [71, 72]. Other anticancer bioactive compounds isolated from $C$. odorata include acacetin, kaempferol-3-O-rutinoside, quercetin-3O-rutinoside, kaempferide and rhamnazin [73-77].

\section{Citrus aurantifolia (Rutaceae)}

C. aurantifolia has been reported to activate the release of caspase- 3 for proapotosis and inhibit the progression of tumor cell cycle at the S-phase [78]. Additionally, C. aurantifolia increased the concentration of tumor infiltrating CD8+ T lymphocytes, and thereby strengthened immunity against cancer cells. C. aurantifolia also hindered the release of BclxL and Mcl-1 (proteins that inhibit apoptosis) [78]. Polymethoxyflavones, which is present in aqueous extract of $C$. aurantifolia, mitigated cancer cell metastasis through the inhibition of cell adhesion and invasion [79]. These bioactive compounds also initiated the release of NK cells leading to the lysis of cancer cells. C. aurantifolia suppressed the action of cyclin-dependent kinases (Cdk) and thereby limited the progression of tumor cell cycle at the G1-phase $[79,80]$. C. aurantifolia extract repressed colon SW-480, pancreatic Panc-28, and breast MDA-MB-453 cancer cells growth [81, 82].

\section{Croton zambesicus (Euphorbiaceae)}

The diterpene, enttrachyloban-3- $\beta$-ol, isolated from dichloromethane leaf extract of $C$. zambesicus has been confirmed to exhibit inhibitory effect on the growth of HeLa cancer cells [83]. Other bioactive compounds with promising anticancer activity from dichloromethane extract of $C$. zambesicus include ent-trachyloban-3-one, ent-18-hydroxytrachyloban-3-one, trans-phytol, isopimara-7, and 15-dien$3-\beta$-ol [73].

\section{Cryptolepis sanguinolenta (Asclepiadaceae)}

The aqueous root extract of $C$. sanguinolenta has shown potency to suppress V79 cell lines (lung fibroblast cells). This effect has been attributed to cryptolepine (an alkaloid), which vastly occurs in C. sanguinolenta. Cryptolepine acts by inhibiting the proliferation and viability of cancer cell lines including V79 [84]. Other alkaloids with anticancer activity from C. sanguinolenta include ascryptolepinoic acid, quindoline, and methyl cryptolepinoate [85]. 


\section{Curcuma longa (Zingiberacea)}

The rhizome of $C$. longa (turmeric) inhibited the growth of cancer cells and also caused the extermination of lymphoma cells and lymphocytes. The anticancer activity of C. longa was attributed to curcumin present in the rhizome [86]. According to Huang et al. [87], C. longa repressed the proliferation of cancer cells and prevented forestomach cancerous growth in animals. The antioxidant and anti-inflammatory activity of $C$. longa makes it a suppressor of breast, colon, lung and liver cancer cells. Curcumin has also shown obstructive activity against cancer cell signaling phases [88]. Generally, curcumin stimulated the apoptotic pathway, initiated cell cycle arrest, and hindered the protein tyrosine kinase activity and the manifestation of c-myc mRNA and bcl-2 mRNA [89]. Ahmad et al. [90] reported the anticancer activity of the ethanolic rhizome extract of $C$. longa against MDA-MB-231 human breast cancer cell line.

\section{Derris scandens (Fabaceae)}

Ethanolic extract of $D$. scandens was reported to repress human colon cancer HT29 cells in concert with radiosensitization. Furthermore, D. scandens provoked HT29 cells death through apoptosis and mitotic inhibition when augmented with $\gamma$-irradiation. D. scandens also acts by suppression of Erk1/2 activation [91]. Certain isoflavones isolated from $D$. scandens with anticancer potentials include glyurallin, derriscandenon B and C, isochandaisone, and derrubone [92].

\section{Enantia chlorantha (Annonaceae)}

The methanolic stem-bark extract of $E$. chlorantha suppressed the proliferation of human colorectal adenocarcinoma (DLD-1 cell line) and human mesothelioma (SPC212 cell line) as well as HepG2 liver cell line [93]. According to Musuyu et al. [94], the stem-bark extract of $E$. chlorantha had deleterious effects on human lung fibroblast cell line. Columbamine, saponins, pseudocolumbamine, and palmatine have been isolated from $E$. chlorantha and were considered to be the anticancer agents in E. chlorantha [95].

\section{Fagara zanthoxyloides (Rutaceae)}

Root extract of $F$. zanthoxyloides is a rich source of fagaronine. This bioactive compound is cytotoxic to human leukemia [96]. The aqueous root extract of $F$. zanthoxyloides reduced the viability and hindered the proliferation of the following prostate cancer cell lines: PC-3, CWR-22, LNCaP, and DU-145 [97].

\section{Glochidion zeylanicum (Euphorbiaceae)}

The triterpinoids and megastigmane glycosides from stem-bark and leaf extracts of G. zeylanicum, respectively, inhibited tumor development, whereas the methanolic root extract was cytotoxic against human cancer cell lines including PC-3. The aqueous root extract of G. zeylanicum also suppressed human prostate cancer PC-3 cell line, human colon cancer HT29 cell line, and human liver cancer HepG2 cell line [8, 98, 99].

\section{Glycyrrhiza glabra (Fabaceae)}

Licochalcone vastly occurs in G. glabra. This bioactive compound exerted apoptotic activity against prostate cancer cells and caused obstruction of the cell cycle through the repression of G2/M cells, cdc2, and cyclin B1. G. glabra reduced the levels of cyclin D1 and the transcription factor E2F, raised cyclin E levels and inhibited CDK 4/6 [101]. Another bioactive compound, isoliquiritigenin, isolated from G. glabra, suppressed prostate cancer proliferation. Isoliquiritigenin initiated the arrest of S- and G2/M-phases and also induced GADD153 mRNA and protein functions that are involved in cell cycle arrest [100]. The aqueous extract of G. glabra exerted anticancer activity against breast cancer (MCF7) and colon cancer (HT-29) cell lines [102].

\section{Goniothalamus macrophyllus (Annonaceae)}

The bioactive compound, goniothalamin, from G. macrophyllus exhibited cytotoxic activity against cervical cancer cells (HeLa), through the initiation of DNA fragmentation and damage as well as the activation of caspase-9, leading to apoptosis [103]. The methanolic root and stem extracts of G. macrophyllus were highly cytotoxic against breast MCF-7 and colon LS-174T cancer cell lines [103, 104]. These anticancer activities of G. macrophyllus were attributed to goniothalamin [104].

\section{Harungana madagascariensis (Guttiferae)}

Stem extracts of $H$. madagascariensis induced the release of nitric oxide, which plays major role in cancer chemotherapy [105]. The methanol as well as the dichloromethane stem-bark extract of $H$. madagascariensis suppressed the growth of CCRF-CEM cancer cell lines [106]. The following bioactive compounds with anticancer potentials have been identified in $H$. madagascariensis: coumarins, anthraquinones, bioflavonoids, anthrone derivatives, and xanthones [107].

\section{Khaya senegalensis (Meliaceae)}

Stem-bark extract of $K$. senegalensis induced apoptosis and inhibited the proliferation of the human colon cancer cell lines: HCT-15, HCA-7, and HT-29 [108]. The methanolic and hydroethanolic stem-bark extracts of $K$. senegalensis have been reported to possess anticancer activity, whereas the methanolic extract specifically suppressed HeLa cervical and $\mathrm{CaCo}-2$ colon cancer cell lines [108]. The hydroethanolic extract of $K$. senegalensis exhibited antimetastatic activity against HepG2 liver 
cancer cell line $[109,110]$. Limonoid compounds such as $3 \alpha, 7 \alpha$-dideacetylkhivorin, 1-O-deacetylkhayanolide E4, khayanolide B2, 6-dehydroxylkhayanolide E5, 1-Oacetylkhayanolide B1, and khayanolide E3 have been isolated from $K$. senegalensis and displayed anticancer activity. For instance, $3 \alpha, 7 \alpha$-dideacetylkhivorin inhibited the proliferation of MCF-7 breast, SiHa cervical, and CaCo2 colon cell lines [111, 112].

\section{Lophira alata (Ochnaceae)}

The methanol stem-bark extract of L. alata was reported to repress the activity of Epstein-Barr virus (EBV) as well its early antigen, and thereby preventing the development of tumors [113]. The anticancer activity of $L$. alata was attributed to bioactive compounds such as azobechalcone A, flavonoids, isolophirachalcone, and lophirone $\mathrm{F}$, which have been isolated from stem-bark of the plant as described by Murakami et al. [114]. The bioactive compound, lophirone A, which is present in $L$. alata retarded tumor growth [113]. Triterpenes, sterols, and polyphenols isolated from the stem-bark of $L$. alata were also reported to be cytotoxic against HepG2, A549, SPC212, CRL2120, MCF-7, and DLD-1 cell lines [93]. Lophirones C and Lophirones B that occurs in stembark of $L$. alata inhibited the proliferation of Ehrlich ascites carcinoma cells [115].

\section{Mangifera indica (Anacardiaceae)}

$M$. indica, popularly called mango, has shown inhibitory effects against the proliferation of cancer cells following the administration of the methanolic stem-bark extract. $M$. indica is a rich source of bioactive compounds such as galloyl glycosides, lupeol, mangiferin, gallotannins, and gallic acid. These bioactive compounds are the major anticancer agents in $M$. indica [116-120]. M. indica suppressed the proliferation of MDA-MB-435 (breast cancer), UACC-257 (melanoma), TK-10 (renal cancer), SK-OV-3 (ovarian cancer), and KM 12 (colon cancer) cell lines [116].

\section{Milicia excelsa (Moraceae)}

The bioactive compounds, namely, neocyclomorusin and cudraxanthone I, from $M$. excelsa were highly repressive against HeLa cancer cell line [121]. These two bioactive compounds were identified in methanolic root-bark extract of M. excelsa [121]. Kuete et al. [122] also reported the deleterious effects of cudraxanthone I on HepG2, HCT-116 and U87MG cell lines. Other anticancer bioactive compounds identified in the root of M. excelsa were betulinic acid, 6-geranylnorartocarpetin, and atalantoflavone [123].

\section{Morinda lucida (Rubiaceae)}

Two major bioactive compounds, namely, $\beta$-sitosterol and molucidin, have been isolated from M. lucida leaves and noted to possess anticancer activity [124]. The $\beta$ sitosterol repressed LNCaP, PC-3, and DU-145 (prostatic carcinoma) cell lines, while molucidin had deleterious actions on stomach cancer (KATO-3) and colon cancer (LoVo) cell lines [124]. The aqueous and methanolic leaf extracts of $M$. lucida hindered the proliferation of human leukemia HL-60 cell line and damaged kidney epithelial cells of monkeys, respectively $[125,126]$. The stem-bark extract of M. lucida was also reported to exert anticancer activity in mice [127]. Other anticancer bioactive compounds present in M. lucida include stigmasterol, oruwacin, digitolutein, ursolic acid, rubiadin-1methyl ether, phytol, cycloartenol, oleanolic acid, damnacantha, campesterol, and molucidin [128-130].

\section{Newbouldia laevis (Bignoniaceae)}

The root-bark extract of $N$. laevis is a rich source of 2acetylfuro-1, 4-naphthoquinone [131]. This bioactive compound suppressed MiaPaCa-2 and CCRF-CEM cancer cell lines [131]. The methanolic leaf extract of $N$. laevis has also been established to exhibit slight inhibitory proliferative action against CCRF-CEM cells [132]. Other anticancer bioactive compounds isolated from $N$. laevis include triterpenoid, tannins, steroids, and quinone derivatives $[133,134]$.

\section{Ocimum gratissimum (Labiatae)}

Caffeic acid (3, 4-dihydroxycinnamic acid) and oleanolic acid from $O$. gratissimum exhibited promising anticancer activity. Report also showed that 3, 4-dihydroxycinnamicacid from O. gratissimum suppressed HeLa cervical cell line [135], whereas oleanolic acid from ethanolic leaf extract of O. gratissimum repressed breast carcinoma, prostate adenocarcinoma, lung carcinoma, colon adenocarcinoma, pancreatic carcinoma, and renal carcinoma in humans [136]. Crude extract of $O$. gratissimum hindered tumor proliferation and suppressed breast cancer development [137]. The aqueous extract of $O$. gratissimum repressed A549 (human lung carcinoma) cell line and as well hindered the development of osteosarcoma cells and bone cancer in humans [138, 139]. Other anticancer bioactive compounds from O. gratissimum are saponins, linalool, eugenol, gerianol, alkaloids, thymol, and citral [140].

\section{Panax ginseng (Araliaceae)}

Ginsenoside Rp1 from P. ginseng inhibited the insulinlike growth factor 1 receptor and thereby prevented human breast cancer cells from multiplying as well as disrupted the anchorage of cells colony. This bioactive compound also induced cell cycle arrest and repressed the growth of cells through apoptosis [141]. The roots 
and rhizomes of $P$. ginseng have also been reported by Kim et al. [142] to inhibit the proliferation of MCF-7 breast cancer cell lines.

\section{Phyllanthus amarus (Euphorbiaceae)}

$P$. amarus extracts have been reported to initiate apoptosis of cancer cells. P. amarus caused obstruction of the G0/G1-phase and S-phase in PC-3 and MeWo cell lines, respectively, and hindered the invasion, migration, and adhesion of these cell lines [143, 144]. Generally, the methanolic extract of $P$. amarus was cytotoxic to lung, breast, pancreas, neuroblastoma, skin, ovarian, glioblastoma, and prostate cancer cell lines. Flavonoids, ellagitannins, polyphenols, triterpenes, sterols, phyllanthin, saponins, and alkaloids have been isolated from $P$. amarus and have been reported to promote anticancer activity [145].

\section{Phyllanthus emblica (Phyllanthacae)}

The aqueous extract of $P$. emblica was cytotoxic against human fibrosarcoma cells (HT1080) by interrupting the invasion, movement, adhesion, and growth of the cells at low level of IC50 [146]. Ellagic acid, chebulagic acid, and gallic acid were among the most studied anticancer bioactive compounds from P. emblica and are known to exhibit antioxidant properties [147-149]. The ethanolic fruit and leaf extracts of P. emblica inhibited cancer cell proliferation as well as reduced the viability of HT-29 colon cancer cell line [150]. Mahata et al. [151] reported the efficacy of the fruit extract of $P$. emblica against cervical cancer cells in vitro.

\section{Picrorhiza kurroa (Plantaginaceae)}

P. kurroa root extract is known to be cytotoxic against cancer cells. The anticancer activity of $P$. kurroa root extract was attributed to the bioactive compounds, namely, apiocynin, cucurbitacines aglycone, and caffeic esters [152]. Picrosides isolated from P. kurroa was reported to possess anticancer activity by its anti-inflammatory and antioxidant actions [153]. The hydroalcoholic extract of P. kurroa was reported to be cytotoxic against cervical HeLa, SiHa, and breast MCF-7, MDA-MB 231 cancer cell lines [154].

\section{Psidium guajava (Myrtaceae)}

The study carried out by Ryu et al. [155] revealed the anticancer potency of $n$-hexane leaf extract of $P$. guajava. The extract induced cell death in prostate PC-3 cancer cell lines through the interruption of the signaling activity associated with tumor formation. The inhibition of the proliferation of breast MCF-7, leukemia P388, prostate DU-145, cervical KB, and HeLa cell lines by the leaf extract of $P$. guajava has also been reported [156]. The anticancer potency of $P$. guajava has been linked to the bioactive compounds, namely, cryptonine, tannins, apigenin, dihydrobenzophenanthridine, lycopene, and saponins present in the plant [156].

\section{Punica granatum (Lythraceae)}

$P$. granatum is rich in ellagic acid and ellagitannins. These bioactive compounds are metabolically transformed to urolithins in the gut microbiota. Urolithins disrupted the cell cycle, prevented cancer cell proliferation, and stimulated apoptosis [80]. The ellagitannin in $P$. granatum extract repressed colorectal cancer in patients [157]. The aqueous fruit extract of $P$. granatum inhibited the proliferation of colon cancer cell lines including HT29, SW620, SW480, and HCT116 [39]. The anticancer activity was attributed to the presence of ellagic acid and punicalagin as well as tannins in P. granatum [39].

\section{Rauvolfia vomitoria (Apocynaceae)}

Ethanolic root extract of $R$. vomitoria has been reported to be cytotoxic to pancreatic, prostate, and ovarian cancer cells [158-160]. The ethanolic root extract of $R$. vomitoria initiated apoptosis and hindered the expansion of tumors in pancreatic cells according to the study done by $\mathrm{Yu}$ and Chen [160]. This anticancer activity was attributed to the presence of $\beta$-carboline in $R$. vomitoria. Furthermore, $R$. vomitoria extract repressed the proliferation as well as induced cell cycle arrest in prostate cancer cells [158]. Additionally, ethanolic root extract of $R$. vomitoria inhibited the development of ovarian cancer cell lines (OVCAR-8, OVCAR-5, SHIN-3) and also initiated apoptosis of cancer cells [159]. Other anticancer bioactive compounds identified in $R$. vomitoria include terpenes, tannins, alkaloids, steroids, saponins, and flavonoids [161].

\section{Scoparia dulcis (Scrophulariaceae)}

The petroleum ether leaf extract of $S$. dulcis repressed NUGC-4 and KATO-3 cell lines. Reports showed that dulcidiol, iso-dulcinol, scopadiol, 4-epi-scopadulcic acid $\mathrm{B}$, and scopanolal were identified to be responsible for its anticancer activity [162]. The ethanolic and methanolic leaf extracts of $S$. dulcis suppressed DU-145 prostate and AGS (human gastric adenocarcinoma) cell lines $[163,164]$.

\section{Tabebuia avellanedae (Bignoniaceae)}

$\beta$-Lapachone is a bioactive compound present in the stem-bark of $T$. avellanedae and has shown high efficacy to ameliorate cancer. Specifically, $\beta$-lapachone hindered the development of HepG2 hepatoma cell line in vivo through DNA fragmentation and the synthesis of apoptotic bodies. This bioactive compound repressed the proteins $\mathrm{Bcl}-2$ and $\mathrm{Bcl}-\mathrm{XL}$ and also stimulated the action 
of Bax, thus supporting apoptosis. $\beta$-Lapachone from $T$. avellanedae also caused the activation of poly (ADP-ribose) polymerase protein and caspase- 3 and caspase- 9 [165].

\section{Thymus vulgaris (Lamiaceae)}

El-khamissi et al. [166] reported the cytotoxic activity of ethanol peel extract of $T$. vulgaris bulb in human breast cancer MCF-7 cell lines. Other bioactive compounds such as diallyl disulfide, diallyl trisulfide, and allicin isolated from T. vulgaris have also shown high potency in the suppression of cancer cells [26].

T. vulgaris oils stimulated the extermination of cancer cells by controlling interferon signaling and the biosynthesis of $\mathrm{N}$-glycan as well as the extracellular signalregulated kinase 5 signaling [167]. According to the study by Soomro et al. [190], the butanol leaf extract of T. vulgaris exhibited slight anticancer activity against HeLa cervical cancer cell lines. This anticancer activity of $T$. vulgaris was attributed to the bioactive compounds such as tannins, triterpenes, sterols, flavonoids, and glycosides isolated from this plant.

\section{Tinospora cordifolia (Menispermaceae)}

T. cordifolia has been used in vitro to exterminate HeLa cancer cells, which confirms the anticancer activity of $T$. cordifolia [168]. The dichloromethane extract of T. cordifolia exhibited high efficacy against cancer cells in mice [168]. The methanolic stem extract of T. cordifolia elicited cytotoxicity and inhibited the proliferation of human breast cancer cell line (MDA-MB-231) in the study carried out by Ahmad et al. [169]. The anticancer bioactive compounds identified in $T$. cordifolia include epoxycleodanediterpene, arabinogalactan, berberine, and phenolics [170].

\section{Tithonia diversifolia (Compositae)}

The ethanolic and methanolic leaf extracts of T. diversifolia inhibited the proliferation of HL-60 and U373 cancer cell lines, respectively $[171,172]$. Bioactive compounds such as tagitinin $\mathrm{C}, 1 \beta$-methoxydiversifolin 3 -O-methyl ether, $1 \beta$ and $2 \alpha$-epoxytagitinin $\mathrm{C}$ are the major anticancer agents present in T. diversifolia and were involved in the inhibition of human Col2 colon cancer cells proliferation and cell death [173]. The methanolic leaf extract of $T$. diversifolia contains tagitinin $\mathrm{C}$, which suppressed $G 2 / M$, reduced cancer cell viability, and stimulated cancer cell autophagy. Tagitinin $\mathrm{C}$ was also reported to be responsible for the anticancer activity of methanolic leaf extract of $T$. diversifolia [174].

\section{Uvaria chamae (Annonaceae)}

The ethanolic stem-bark extract of $U$. chamae exhibited anticancer activity through the repression of lymphocytic leukemia proliferation, whereas the ethanolic root extract mitigated tumor marker levels in rats [175]. The bioactive compounds isolated from $U$. chamae with anticancer potentials include dichamanetin, diuvaretin, uvaretin, chamanetin, pinocembrin, isouvaretin, pinostrobin, and isochamanetin [4].

\section{Vernonia amygdalina (Compositae)}

Studies showed that $V$. amygdalina extracts inhibited the proliferation of BT-549 and MCF-7 breast cancer cell lines [176]. Steroid glycosides have been linked to the anticancer agent of $V$. amygdalina [176]. The chloroform extract of $V$. amygdalina suppressed KB cell lines. The peptide known as edotide in the leaves of $V$. amygdalina inhibited breast cancer [176-178].

\section{Zanthoxylum nitidum (Rutaceae)}

The root of $Z$. nitidum is a rich source of nitidine. Nitidine is an anticancer agent that acts as an inhibitor of topoisomerases I and II activities [179, 180]. Benzophenanthridine isolated from $Z$. nitidum roots was reported to exert cytotoxic and antiproliferative activities against lung (A549), cervical (HeLa), and liver (SMMC-7721) cancer cell lines [181].

\section{Zingiber officinale (Zingiberaceae)}

The anticancer bioactive compounds, namely, 10gingerol, 10-shogaol, 6-gingerol, and 6-shogaol are present in Z. officinale. These bioactive compounds hindered the proliferation of $\mathrm{PC}-3$ prostate cancer cell line [182]. 6-shogaol inhibited the proliferation of Huh7, HepG2, and SMMC-7721 (human hepatocellular carcinoma) cell lines [183, 184]. 10-gingerol was reported to inhibit metastasis [185]. The ethyl acetate extract of $Z$. officinale has been reported by Li et al. [186] to suppress the proliferation of MCF-7 breast, HepG2 liver, and KYSE-150 esophageal cancer cell lines.

\section{Classifications of bioactive compounds with anticancer activity}

The major classes of bioactive compounds from medicinal plants with anticancer activity include the polyphenols, flavonoids, alkaloids, saponins, triterpenes, tannins, and quinones. These bioactive compounds exerted antiproliferative, cytotoxic, cytostatic, antimetastatic, apoptotic, and antioxidative actions as well as provoked cell cycle arrest, inhibited angiogenesis and reduced cancer cell viability.

\section{Polyphenols}

Polyphenols have been reported to possess antioxidant and cytotoxic activities against cancer cells [191-193]. The anti-carcinogenicity of the polyphenols is hinged on their capabilities to initiate apoptosis. Polyphenols 
regulate the assemblage of copper ions on chromatin. The copper ions assemblies on chromatin, engendered by the polyphenols such as resveratrol, elicit DNA disintegration [191].

Plant polyphenols also interacted and interfered with cancer cells proteins and thereby inhibited the growth of these cells. Polyphenols bonded directly with cancenogens disrupted their cancer promoting activities through acetylation, phosphorylation, and methylation mechanisms. For instance, a polyphenol-curcumin was reported to suppress the actions of tumor necrosis factor (TNF) in cell lines [194]. Curcumin also stimulated the apoptotic pathway, initiated cell cycle arrest and hindered the protein tyrosine kinase activity as well as the manifestation of c-myc mRNA and bcl-2 mRNA [89].

\section{Flavonoids}

The flavonoids were reported to be toxic to cancer cells and exhibited high free radical scavenging activity [195]. The following flovonoids, alpinumisoflavone and 4'methoxy licoflavanone, initiated the apoptosis of human leukemia via extrinsic and intrinsic signaling pathways; the mitochondria of the cell were destroyed in the process, and thereby lead to cell death [196]. Xia et al. [197] reported the high anticancer efficacy at low concentrations of the flavonoids.

The flavonoids hindered NF- $\mathrm{KB}$ expression. NF- $\mathrm{kB}$ is a protein complex that is required for the angiogenesis, proliferation and survival of cancer cells [198]. The flavonoid, isoliquiritigenin, induced the obstruction of S-phase and G2/M-phase as well as activated GADD153 mRNA and protein functions involved in cell cycle arrest [100].

\section{Alkaloids}

These bioactive compounds disrupted tumorigenesis as well as the progression of tumor cell growth [199-201]. The alkaloids inhibited cancer cells proliferation through the initiation of cell apoptosis and by stimulating the termination of cancer cell cycle at G1-phase or G2/Mphase [199, 202, 203]. The alkaloids induced cancer cell autophagy and endoplasmic reticulum damage [202, 204]. The alkaloids elicited their anticancer efficacy majorly by acting as inhibitor of tumor invasion and metastasis [205, 206]. Jie et al. [207] and Hamsa and Kuttan [208] reported the ability of alkaloids to inhibit tumor angiogenesis. These bioactive compounds reduced cellular glutathione (GSH) levels by interacting directly with GSH and thus stimulated the generation of ROS [209212]. The alkaloids are also involved in the inhibition of NF-кB activation [199, 202].

\section{Saponins}

Saponins exhibited immunomodulatory activities through cytokine interplay [199]. Cytotoxic and cytostatic actions were among the major anticancer mechanisms of saponins $[213,214]$.

The triterpene saponins repressed the growth of cancer cells and activated apoptosis [215]. Saponins exerted antiproliferative activity by clustering in the S-phase and causing G2/M-phase obstruction, as well as the inhibition of the expression of $\mathrm{p} 21$ and the cyclin-dependent kinase activity. Saponins activate cancer cell apoptosis through the stimulation of caspase- 3 and caspase-9, and the disintegration of poly (ADP-ribose) polymerase accompanied by DNA fragmentation and condensation of nuclear chromatin [216, 217]. The steroidal saponins promoted cancer cell cycle arrest and induced apoptosis, as well as acted as antitumor agents [218]. The saponins, ginsenoside Rp1, induced cancer cell cycle arrest through the repression of $\mathrm{G} 2 / \mathrm{M}$ cells, cdc2, and cyclin B1 [102].

\section{Triterpenes}

Triterpenes such as 3-O-acetyl-11-keto- $\beta$-boswellic acid initiated tumor cell apoptosis through the stimulation of the death receptor DR-5 signaling pathway [219, 220]. Triterpenes also initiated apoptosis of tumor cells through the upregulation and downregulation of Bax (proapoptotic protein) and $\mathrm{Bcl}-2$ (antiapoptotic protein) secretion [221-225]. Triterpenes have also induced apoptosis by raising the levels of intracellular $\mathrm{Ca}^{2+}$ and stimulating the release of P53 [226].

Triterpenes induced cell cycle arrest at the G2/M-, G1-, and S-phases by mitigating cyclin Bi/cdc2 action, upregulation of P21 effect and the repression of cyclin A expression, respectively [221, 224, 227]. Triterpenes hindered the proliferation of tumor cells through the obstruction of the Akt/mTOR signaling pathway [228, 229]. Triterpenoids hindered the invasion and migration of cancer cells by mitigating the expression of the proteins MMP-2 and MMP-9 as well as gelatinase activity [230]. This class of bioactive compounds suppressed tumor angiogenesis by inhibiting the secretion of the angiogenic factors: bFGF and VEGF-A and the vascular endothelial growth factor [231, 232].

\section{Tannins}

The anticancer pharmacological actions of the tannins, such as ellagiatannin, have been reported to be involved in cyclin E upregulation and cyclins A and B1 downregulation, cell cycle obstruction at the S-phase, and apoptosis activation through the intrinsic pathway by downregulating bcl-XL accompanied by the cytosolic mitochondrial secretion of cytochrome $C$, as well as induction of caspase-3 and caspase-9 [233].

According to Jia et al. [234], tannins such as corilagin exhibited anti-inflammatory action, inhibited the growth of cancer cells by obstructing the TGF- $\beta /$ AKT/ERK/Smad 
signaling pathways, as well as induced cell cycle arrest at the G2/M-phase. Tannins also elicited apoptosis of cancer cells through the stimulation of sub-G1 fraction and condensation of chromosome as well as DNA disintegration [235].

\section{Quinones}

Quinones such as aloe-emodin inhibited the proliferation of cancer cells through the obstruction of the following cell cycles: G1-, G2/M- or S-phases [236-240]. Quinones stimulated DNA damage by inducing ROS [241]. Quinones activated cancer cell apoptosis by stimulating c-Jun $\mathrm{N}$-terminal kinase, caspases, the Fas pathway and p53 pathway [236, 240, 242, 243].

The anticancer activity of the quinones has also been attributed to the ability of these bioactive compounds to mitigate the expression of urokinase, MMP-2 and MMP-9 proteins as well as nuclear translocation inhibition [139, $244,245]$. The quinone, $\beta$-lapachone, was reported to induce DNA fragmentation and the synthesis of apoptotic bodies, repressed the proteins Bcl-2 and Bcl-XL and stimulated the action of Bax, and thereby promoted cancer cell apoptosis, activated poly (ADP-ribose) polymerase protein and caspase- 3 and caspase-9 [165].

\section{Anticancer drugs derived from Nigerian medicinal plants after undergoing research and clinical trials}

Drugs derived from medicinal plant in the form of herbal remedies are preferred to synthetic drugs for the treatment of cancer because; for the most part, they are associated with fewer side effects, inexpensive, and readily available. These herbal remedies can be easily consumed as components of the patient's dietary intake $[246,247]$. The anticancer activity of medicinal plants are dependent on their bioactive compounds, although some of these bioactive compounds such as lectins, some taxanes, cyanogenic glycosides, and lignans are less tolerated and toxic to humans [248, 249]. Nevertheless, research has also shown that plants derived drugs exhibited anticancer activity with little or no toxic effects on normal cells and have been subjected to clinical trials for the development of therapeutics [247].

The anticancer drugs derived from Nigerian medicinal plants that have undergone various stages of

Table 2 Anticancer drugs derived from Nigerian medicinal plants after undergoing research and clinical trials

\begin{tabular}{lll}
\hline Anticancer drug & Plant source & $\begin{array}{l}\text { Bioactive compor } \\
\text { involved }\end{array}$ \\
\hline Paclitaxel (Taxol) & Taxus brevifolia (Taxaceae) & Taxane \\
& & \\
$\begin{array}{l}\text { Vinblastine, Vinflunine } \\
\text { Vinorelbine, Vindesine, }\end{array}$ & $\begin{array}{l}\text { Catharanthus roseus } \\
\text { Vincristine, }\end{array}$ & Vinca alkaloids \\
Pomiferin & $\begin{array}{l}\text { Maclura pomifera (Moraceae); } \\
\text { Derris malaccensis } \\
\text { (Leguminosae) }\end{array}$ & Isoflavonoid \\
Epigallacotechin-3-gallate & Camellia sinensis (Theaceae) & Catechin
\end{tabular}

Sulphoraphane

Brassica rapa (Brassicaceae)

Isotiocynanate

Flavopiridol

Dysoxylum binectariferum (Meliaceae)

Epipodophyllotoxin

Combretastatin A-4 phosphate

Podophyllum peltatum (Berberidaceae)

Combretum caffrum (Combretaceae)

Noscapine

Papaver somniferum (Papaveraceae)

Roscovitine

Olomucine
Synthetic flavonoid derivative, rohitukine

Podophyllotoxin isomer

Water-soluble analog of combretastatin

Noscapine alkaloid

\section{Pharmacological actions}

Disruption, polymerization, and stabilization of the microtubules stimulate cancer cell apoptosis, hinder translational machinery, interfere with the synthesis of the spindle, and inhibit mitosis.

Antitumor effects, proapoptotic activity, and obstruction of the cell cycle inhibits mitosis, attaches to $\beta$-tubulin, and interferes with microtubule activity.

Inhibitor of histone deacetylases induces DNA fragmentation, cytotoxic to cancerous cells, and causes proapoptosis.

Inhibits the action of certain kinases, hinders the proliferation of cancer cells, exerts antioxidant effects, and inhibits carcinogenesis caused by chemicals and UV radiations.

Hinders the development of breast tumors, inhibits the proliferation of cancer cells, and stimulates phase 2 enzymes for detoxification.

nhibits cell growth, immune system modulation, exerts tyrosine kinase activity, and ameliorates inflammation.

Disrupts cell cycle and causes proapoptosis of cancer cells.

Inhibits angiogenesis, vascular shutdown, and necrosis of tumor cells.

Inhibition of cancer cells proliferation hinders the growth of tumors and interferes with microtubules.

Inhibits the continuation of the cell cycle and inhibits cyclin-dependent kinases. 
research and clinical trials include paclitaxel (Taxol), vinblastine, vinflunine, vinorelbine, vindesine, vincristine, pomiferin, epigallacotechin-3-gallate, sulphoraphane, flavopiridol, epipodophyllotoxin, combretastatin A-4 phosphate, noscapine, and roscovitine. The Nigerian plants from which anticancer drugs are derived, the bioactive compounds that exert the anticancer activity as well as the associated pharmacological actions are presented in Table 2.

\section{Conclusion}

In this review, the 51 Nigerian medicinal plants were reported to exhibit anticancer activity of the prostate, cervices, lung, skin, colon, esophagus, blood, ovary, central nervous system/brain, breast, stomach, pancreas, larynx, and kidney, indicating the possible use of these medicinal plants as anticancer drug agents. The major classes of bioactive compounds indicated to be responsible for the anticancer activity include the polyphenols, flavonoids, alkaloids, saponins, triterpenes, tannins, and quinones. The major anticancer pharmacological actions of these bioactive compounds were antiproliferative, cytotoxic, cytostatic, antimetastatic, apoptotic, and antioxidative as well as provoked cell cycle arrest, inhibition of angiogenesis and reduction of cancer cell viability. This review also reported 14 anticancer drugs derived from Nigerian medicinal plants that have undergone various stages of research and clinical trials. These anticancer drugs include paclitaxel (Taxol), vinblastine, vinflunine, vinorelbine, vindesine, vincristine, pomiferin, epigallacotechin-3-gallate, sulphoraphane, flavopiridol, epipodophyllotoxin, combretastatin A-4 phosphate, noscapine, and roscovitine.

The present review showed that leaf, root, and stembark extracts of the Nigerian medicinal plants were principal sources of vast majority of bioactive compounds that exhibited anticancer activity. Therefore, further emphases on the investigations of anticancer activity of these Nigerian medicinal plants parts, namely, the leaf, root, and stem-bark extracts is recommended. Nigerian medicinal plants can be harnessed to provide for readily available and inexpensive anticancer drugs in the future because the plants reported in this review showed promising anticancer activity.

\section{Acknowledgements}

Not applicable.

Studies involving plants statement

Not applicable

\section{Authors' contributions}

FOO/PCC conceived and designed the scope of the report. FOO/PCC/CMC/ CCE contributed in writing the paper. FOO/PCC revised and edited the manuscript draft. CMC/CCE authors were the resource persons who provided all the necessary materials for writing the manuscript. All authors have read and approved the manuscript in the present form and gave the permission to submit the manuscript for publication.
Funding

The authors did not receive financial support and sponsorship from individuals or organizations/institutions.

Availability of data and materials

Data and material are available upon request.

\section{Declarations}

Ethics approval and consent to participate Not applicable.

\section{Consent for publication}

Not applicable

\section{Competing interests}

The authors declare no competing interests.

\section{Author details}

${ }^{1}$ Department of Biochemistry, Imo State University, Owerri, Nigeria.

${ }^{2}$ Department of Biochemistry, Federal University of Technology, Owerri, Nigeria. ${ }^{3}$ Department of Chemistry, Imo State University, Owerri, Nigeria.

Received: 14 December 2020 Accepted: 4 March 2021

Published online: 20 March 2021

\section{References}

1. Ferlay J, Soerjomataram I, Dikshit R, Eser S, Mathers C, Rebelo M (2015) Cancer incidence and mortality worldwide: Sources, methods and major patterns in GLOBOCAN 2012. Int J Cancer 136(5):359-386

2. GBD (2015) Mortality and causes of death collaborators: global, regional, and national life expectancy, all-cause mortality, and cause-specific mortality for 249 causes of death, 1980-2015: A systematic analysis for the global burden of disease study 2015. Lancet 388(10053):1459-1544

3. Tyagi N, Sharma GN, Shrivastava B, Saxena P, Kumar N (2017) Medicinal plants: used in anti-cancer treatment. Int J Res Dev Pharm L Sci 6(5):27322739

4. Lasswell WL Jr, Hufford CD (1977) Cytotoxic C-benzylated flavonoids from Uvaria chamae. J Organomet Chem 42(8):1295-1302. https://doi.org/10.1 021/jo00428a006

5. Rashid H, Gafur GM, Sadik RMAA (2002) Biological activities of a new derivative from Ipomoea turpithum. Pak J Biol Sci 5:968-969

6. Pledgie-Tracy A, Sobolewski MD, Davidson NE (2007) Sulforaphane induces cell type-specific apoptosis in human breast cancer cell lines. Mol Cancer Ther 6(3):1013-1021. https://doi.org/10.1158/1535-7163.MCT-06-0494

7. Risinger AL, Giles FJ, Mooberry SL (2009) Microtubule dynamics as a target in oncology. Cancer Treat Rev 35(3):255-261. https://doi.org/10.1016/j.ctrv.2 008.11 .001

8. Sharma H, Parihar L, Parihar P (2011a) Review on anticancerous properties of some medicinal plants. J Med Plant Res 5(10):1818-1835

9. Chikezie PC, Ojiako OA, Nwufo KC (2015a) Overview of anti-diabetic medicinal plants: the Nigerian research experience. J Diabetes Metab 6:546

10. Solowey E, Lichtenstein M, Sallo S, Paavilainen H, Solowet E, LorberboumGalski H (2014) Evaluating medicinal plants for anticancer activity. Sci World J $721402: 12$

11. Chikezie PC, Ekeanyanwu RC, Chile-Agada AB, Ohiagu FO (2019) Comparative FT-IR analysis of chloroform fractions of leaf extracts of Anacardium occidentale, Psidium guajava and Terminalia catappa. J Basic Pharmacol Toxicol 3(1):1-6

12. Shoeb M (2006) Anti-cancer agents from medicinal plants. Bang J Pharmacol 1(2):35-41

13. Sultana S, Asif HM, Nazar HMl, Akhtar N, Rehman JU, Rehman RU (2014) Medicinal plants combating against cancer - a green anticancer approach. Asian Pac J Cancer Prev 15(11):4385-4394. https://doi.org/10.7314/APJCP.2 014.15.11.4385

14. Quiroga R, Meneses L, Bussmann RW (2012) Medicinal ethnobotany in Huacareta (Chuquisaca, Bolivia). J Ethnobiol Ethnomed 8(1):29. https://doi. org/10.1186/1746-4269-8-29

15. Chikezie PC, Ibegbulem CO, Mbagwu FN (2015b) Bioactive principles from medicinal plants. Res J Phytochem 9(3):88-115. https://doi.org/10.3923/ rjphyto.2015.88.115 
16. Swamy MK, Sinniah UR (2016) Patchouli (Pogostemon cablin Benth.): Botany, agrotechnology and biotechnological aspects. Ind Crop Prod 87:161-176. https://doi.org/10.1016/j.indcrop.2016.04.032

17. Arumugam G, Swamy MK, Sinniah UR (2016) Plectranthus amboinicus (Lour.) Spreng: botanical, phytochemical, pharmacological and nutritional significance. Mole 21(4): 369

18. Suárez Al, Chávez K (2018) Appraisal of medicinal plants with anticancer properties in South America. In: Akhtar MS, Swamy MK (eds) Anticancer plants: properties and application. Springer Nature, Singapore, pp 229-283. https://doi.org/10.1007/978-981-10-8548-2_11

19. Svoboda GH, Poore GA, Simpson PJ, Boder GB (1996) Alkaloids of Acronychia baveri Schott: isolation of the alkaloids and a study of the antitumor and other biological properties of acronycine. J Pharm Sci 55(8): 758-768

20. Adebayo AH, Tan NH, Akindahunsi AA, Zeng GZ, Zhang YM (2010) Anticancer and antiradical scavenging activity of Ageratum conyzoides L. (Asteraceae). Pharmacogn Mag 6(21):62-66

21. Bayala B, Bassole IH, Gnoula C, Nebie R, Yonli A, Morel L (2014) Chemical composition, antioxidant, anti-inflammatory and anti-proliferative activities of essential oils of plants from Burkina Faso. PLoS One 9(3):e92122. https:// doi.org/10.1371/journal.pone.0092122

22. Kuete V, Tchinda CF, Mambe FT, Beng VP, Efferth T (2016) Cytotoxicity of methanol extracts of 10 Cameroonian medicinal plants towards multifactorial drug-resistant cancer cell lines. BMC Complement Altern Med 16(1): 267. https://doi.org/10.1186/s12906-016-1253-3

23. Noundou XS, Krause RW, van Vuuren SF, Ndinteh DT, Olivier DK (2016) Antibacterial effects of Alchornea cordifolia (Schumach. and Thonn.) Müll. Arg extracts and compounds on gastrointestinal, skin, respiratory and urinary tract pathogens. J Ethnopharmacol 179:76-82. https://doi.org/10.101 6/j.jep.2015.12.043

24. Thomson M, Ali M (2003) Garlic (Allium sativum): a review of its potential use as an anti- cancer agent. Curr Cancer Drug Targets 3(1):67-81. https:// doi.org/10.2174/1568009033333736

25. Adaki S, Adaki R, Shah K, Karagir A (2014) Garlic: review of literature. Indian J Cancer 51(4):577-581. https://doi.org/10.4103/0019-509X.175383

26. Petrovic V, Nepal A, Olaisen C, Bachke S, Hira J, Søgaard CK (2018) Anticancer potential of home made fresh garlic extract is related to increased endoplasmic reticulum stress. Nutr 10(4):450

27. Kerr JF, Wyllie AH, Currie AR (1972) Apoptosis: a basic biological phenomenon with wide range implications in tissue kinetics. $\mathrm{Br}$ I Cancer 26(4):239-257. https://doi.org/10.1038/bjc.1972.33

28. Padmaharish V, Lakshmi T (2017) Anticancer activities of medicinal plants-an update. J Pharm Sci Res 9(4):432-440

29. Balogun OS, Ajayi OS, Agberotimi BJ (2016) A cytotoxic indole alkaloid from Alstonia boonei. J Biol Act Prod Fr Nat 6(4):347-351

30. Ojewole JAO (1984) Studies on the pharmacology of echitamine, an alkaloid from the stem-bark of Alstonia boonei L. (Apocynaceae). Int I Crude Drug Res 22(3):121-143. https://doi.org/10.3109/13880208409070663

31. Jaganathan SK, Supriyanto E (2012) Antiproliferative and molecular mechanism of eugenol-induced apoptosis in cancer cells. Mol 17(6):62906304. https://doi.org/10.3390/molecules 17066290

32. Save SA, Lokhande RS, Chowdhary AS (2015) Determination of 1, 2benzenedicarboxylic acid, bis (2-ethylhexyl) ester from the twigs of Thevetia peruviana as a Colwell biomarker. J Innov Pharm Biol Sci 2(3):349-362

33. Babatunde O (2017) GC-MS analysis of leaf, stem-bark and root extracts of Alstonia boonei. Afr J Pharm Pharmacol 11(46):577-581. https://doi.org/10. 5897/AJPP2017.4864

34. Konan NA, Lincopan N, Collantes Díaz IE, de Fátima JJ, Tiba MM, Amarante Mendes JG (2012) Cytotoxicity of cashew flavonoids towards malignant cell lines. Exp Toxicol Pathol 64(5):435-440. https://doi.org/10.1016/j.etp.2010.10. 010

35. Taiwo BJ, Fatokun AA, Olubiyi OO, Bamigboye-Taiwo OT, van Heerden FR, Wright CW (2017) Identification of compounds with cytotoxic activity from the leaf of the Nigerian medicinal plant, Anacardium occidentale L. (Anacardiaceae). Bioorg Med Chem 25(8):2327-2335. https://doi.org/10.101 6/j.bmc.2017.02.040

36. Obembe OO, Ige AO (2016) Sperm parameters of male Wistar rats treated with Anacardium occidentale L. leaf extract. Res J Heal Sci 4(1):83-89

37. Olugbami JO, Damoiseaux R, France B, Onibiyo EM, Gbadegesin MA, Sharma S (2017a) A comparative assessment of antiproliferative properties of resveratrol and ethanol leaf extract of Anogeissus leiocarpus (DC) Guill and
Perr against HepG2 hepatocarcinoma cells. BMC Complement Altern Med 17(1):381. https://doi.org/10.1186/s12906-017-1873-2

38. Salau AK, Yakubu M, Oladiji A (2013) Cytotoxic activity of aqueous extracts of Anogeissus leiocarpus and Terminalia avicennioides root barks against Ehrlich ascites carcinoma cells. Indian J Pharm 45(4):381-385. https://doi. org/10.4103/0253-7613.115023

39. Seeram NP, Adams LS, Henning SM, Niu Y, Zhang Y, Nair MG (2005) In vitro antiproliferative, apoptotic and antioxidant activities of punicalagin, ellagic acid and a total pomegranate tannin extract are enhanced in combination with other polyphenols as found in pomegranate juice. J Nutr Biochem 16(6):360-367. https://doi.org/10.1016/j.jnutbio.2005.01.006

40. Shuaibu MN, Wuyep PA, Yanagi T, Hirayama K, Tanaka T, Kouno I (2008) The use of microfluorometric method for activity-guided isolation of antiplasmodial compound from plant extracts. Parasitol Res 102(6):11191127. https://doi.org/10.1007/s00436-008-0879-6

41. Fernandes A, Fernandes I, Cruz L, Mateus N, Cabral M, de Freitas V (2009) Antioxidant and biological properties of bioactive phenolic compounds from Quercus suber L. J Agric Food Chem 57(23):11154-11160. https://doi. org/10.1021/jfg02093m

42. William CS, Kwok NL (2007) In vitro and in vivo anti-tumor effects of Astragalus membranaceus. Cancer Lett 252(1):43-54

43. Zhou R, Chen H, Chen J (2018) Extract from Astragalus membranaceus inhibits breast cancer cells proliferation via PI3K/AKT/mTOR signaling pathway. BMC Complement Altern Med 18(83):1-8

44. Wei QG, Liang ZL, Zhuo YH (2013a) Anti-proliferative effects of Atractylis lancea (Thunb.) DC. via down-regulation of the c-myc/hTERT/telomerase pathway in Hep-G2 Cells. Asian Pac J Cancer Prev 14:6363-6367

45. Zhao M, Wang Q, Ouyang Z, Han B, Wang W, Wei Y, Wu Y, Yang B (2014) Selective fraction of Atractylodes lancea (Thunb.) DC. and its growth inhibitory effect on human gastric cancer cells. Cytotechnol 66(2):201-208. https://doi.org/10.1007/s10616-013-9559-1

46. Rivlin N, Brosh R, Oren M, Rotter V (2011) Mutations in the p53 tumor suppressor gene important milestones at the various steps of tumorigenesis. Genes Cancer 2(4):466-474. https://doi.org/10.1177/1947601 911408889

47. Antoun GR, Ali-Osman F (2013) Mutational status of the p53 tumor suppressor gene is associated with expression of GSTP1 allelic variants in human GBM. Cancer Res 73(8):783

48. Yu SZ (1995) Primary prevention of hepatocellular carcinoma. J Gastroenterol Hepatol 10(6):674-682. https://doi.org/10.1111/j.1440-1746.1 995.tb01370.x

49. Husain S, Alam MA, Jahan N, Ahmed S, Kauser HS (2014) Sibr (Aloe vera) and its therapeutic efficacy described in Unani medicine: a review. I Sci Innov Res 3(5):545-551

50. Kumar RS, Rajkapoor B, Perumal P (2011) In vitro and in vivo anticancer activity of Indigofera cassioides Rottl. Ex. DC. Asian Pac J Trop Med 4(5):379385. https://doi.org/10.1016/S1995-7645(11)60108-9

51. Wei AH, Brown M, Guthridge M (2013b) The regulation of mitochondrial metabolism by the $\mathrm{Bcl}-2$ family of pro-survival proteins: new therapeutic opportunities for targeting cancer cells. J Hematol Thromb Dis 1(4):1-3

52. Mahapatra S, Karnes RJ, Holmes MW, Young CYF, Cheville JC, Kohli M (2011) Novel molecular targets of Azadirachta indica associated with inhibition of tumor growth in prostate cancer. AAPS J 13(3):365-367. https://doi.org/1 0.1208/s12248-011-9279-4

53. Hao F, Kumar S, Yadav N, Chandra D (2014) Neem components as potential agents for cancer prevention and treatment. Biochim Biophys Acta 1846(1): 247-257. https://doi.org/10.1016/j.bbcan.2014.07.002

54. Patel SM, Venkata KC, Bhattacharyya P, Sethi G, Bishayee A (2016) Potential of neem (Azadirachta indica $\mathrm{L}$.) for prevention and treatment of oncologic diseases. Semin Cancer Biol 40-41:100-115. https://doi.org/10.1016/j.semca ncer.2016.03.002

55. Bharali R, Azad MR, Tabassum J (2003) Chemopreventive action of Boerhaavia diffusa on DMBA- induced skin carcinogenesis in mice. Indian J Physiol Pharmacol 47(4):459-464

56. Muthulingam M, Chaithanya KK (2018) In vitro anticancer activity of methanolic leaf extract of Boerhaavia diffusa Linn., against MCF-7 cell line. Drug Invent Today 10(2):3107-3111

57. Venkatajothi R (2017) In vitro anti-cancer activity of Boerhaavia diffusa Linn. Int J Curr Res Biol Med 2(3):20-24. https://doi.org/10.22192/ijcrbm.2017.02.03.004

58. Schuster R, Holzer W, Doerfler $H$, Weckwerth W, Viernstein $H$, Okonogi S (2016) Cajanus cajan - a source of PPARc activators leading to anti- 
inflammatory and cytotoxic effects. Food Funct 7(9):3798-3806. https://doi. org/10.1039/C6FO00689B

59. Ashidi JS, Houghton PJ, Hylands PJ, Efferth T (2010) Ethnobotanical survey and cytotoxicity testing of plants of South-western Nigeria used to treat cancer, with isolation of cytotoxic constituents from Cajanus cajan Mill sp. leaves. J Ethnopharmacol 128(2):501-512. https://doi.org/10.1016/j.jep.2010. 01.009

60. Sarkar R, Mandal N (2011) In vitro cytotoxic effect of hydroalcoholic extracts of medicinal plants on Ehrlich's ascites carcinoma (EAC). Int J Phytomed 3(3):370-380

61. Zhang N, Shen X, Jiang X, Cai J, Shen X, Hu Y (2018) Two new cytotoxic stilbenoid dimers isolated from Cajanus cajan. J Nat Med 72(1):304-309. https://doi.org/10.1007/s11418-017-1138-x

62. Pal D, Mishra P, Sachan N, Ghosh AK (2011) Biological activities and medicinal properties of Cajanus cajan (L) Millsp. J Adv Pharm Technol Res 2(4):207-214. https://doi.org/10.4103/2231-4040.90874

63. Tang R, Tian RH, Cai JZ, Wu JH, Shen XL, Hu YJ (2017) Acute and subchronic toxicity of Cajanus cajan leaf extracts. Pharm Biol 55(1):1740-1746. https://doi.org/10.1080/13880209.2017.1309556

64. Valcic S, Timmermann BN, Alberts DS (1996) Inhibitory effect of six green tea catechins and caffeine on the growth of four selected human tumor cell lines. Anti-Cancer Drugs 7(4):461-468. https://doi.org/10.1097/00001 813-199606000-00011

65. Nakahara K, Onishi KM, Ono H, Yoshida M, Trakoontivakorn G (2001) Antimutagenic activity against trp-P-1 of the edible Thai plant: Oroxylum indicum Vent. Biosci Biotechnol Biochem 65(10):2358-2360. https://doi.org/1 $0.1271 / \mathrm{bbb} .65 .2358$

66. Pandey S, Walpole C, Cabot PJ, Shaw PN, Batra J, Hewavitharana AK (2017) Selective anti-proliferative activities of Carica papaya leaf juice extracts against prostate cancer. Biomed Pharmacother 89:515-523. https://doi.org/1 0.1016/j.biopha.2017.02.050

67. Otsuki N, Dang NH, Kumagai E, Kondo A, Iwata S, Morimoto C (2010) Aqueous extract of Carica papaya leaves exhibits anti-tumor activity and immunomodulatory effects. J Ethnopharmacol 127(3):760-767. https://doi. org/10.1016/j.jep.2009.11.024

68. Nguyen TT, Parat MO, Hodson MP, Pan J, Shaw PN, Hewavitharana AK (2015) Chemical characterization and in vitro cytotoxicity on squamous cell carcinoma cells of Carica papaya leaf extracts. Toxins (Basel) 8(1):7. https:// doi.org/10.3390/toxins8010007

69. Bhagat M, Saxena A (2010) Evaluation of Cassia occidentalis for in vitro cytotoxicity against human cancer cell lines and antibacterial activity. Indian J Pharm 42(4):234-237. https://doi.org/10.4103/0253-7613.68428

70. Taiwo FO, Akinpelu DA, Aiyegoro OA, Olabiyi S, Adegboye MF (2013) The biocidal and phytochemical properties of leaf extract of Cassia occidentalis Linn. Afr J Microbiol Res 7(27):3435-3441

71. Kouamé PB, Jacques C, Bedi G, Silvestre V, Loquet D, Barillé-nion S (2012) Phytochemicals isolated from leaves of Chromolaena odorata: Impact on viability and clonogenicity of cancer cell lines. Phyther Res 27(6):835-840

72. Hung TM, Cuong TD, Dang NH, Zhu S, Long PQ, Komatsu K (2011) Flavonoid glycosides from Chromolaena odorata leaves and their in vitro cytotoxic activity. Chem Pharm Bull (Tokyo) 59(1):129-131. https://doi.org/1 $0.1248 /$ cpb.59.129

73. Block S, Baccelli C, Tinant B, Van Meervelt L, Rozenberg R, Habib Jiwan JH (2004) Diterpenes from the leaves of Croton zambesicus. Phytochem 65(8): 1165-1171. https://doi.org/10.1016/j.phytochem.2004.02.023

74. Singh RP, Agrawal P, Yim D, Agarwal C, Agarwal R (2005) Acacetin inhibits cell growth and cell cycle progression and induces apoptosis in human prostatecancer cells: structure-activity relationship with linarin and linarin acetate. Carcinog 26(4):845-854. https://doi.org/10.1093/ca rcin/bgi014

75. Nath LR, Gorantla JN, Joseph SM, Antony J, Thankachan S, Menon DB (2015) Kaempferide, the most active among the four flavonoids isolated and characterized from Chromolaena odorata, induces apoptosis in cervical cancer cells while being pharmacologically safe. RSC Adv 5(122):100912100922. https://doi.org/10.1039/C5RA19199H

76. Yu Y, Cai W, Pei CG, Shao Y (2015) Rhamnazin, a novel inhibitor of VEGFR2 signaling with potent antiangiogenic activity and antitumor efficacy. Biochem Biophys Res Commun 458(4):913-919. https://doi.org/10.1016/j. bbrc.2015.02.059

77. Ben Sghaier M, Pagano A, Mousslim M, Ammari Y, Kovacic H, Luis J (2016) Rutin inhibits proliferation, attenuates superoxide production and decreases adhesion and migration of human cancerous cells. Biomed Pharmacother 84:1972-1978. https://doi.org/10.1016/j.biopha.2016.11.001

78. Zhao Y, Sun H, Ma L, Liu A (2017) Polysaccharides from the peelsof Citrus aurantifolia induces apoptosis in transplanted $\mathrm{H} 22$ cells in mice. Int J Biol Macromol 101:680-689. https://doi.org/10.1016/j.j.jbiomac.2017.03.149

79. Park HR, Park SB, Hong HD, Suh HJ, Shin KS (2017) Structural elucidation of anti-metastatic rhamnogalacturonan II from the pectinase digest of citrus peels (Citrus unshiu). Int J Biol Macromol 94(Pt A):161-169. https://doi.org/1 0.1016/j.jijbiomac.2016.09.100

80. Roy A, Bharadvaja N (2017) Effect of different culture media on shoot multiplication and stigmasterol content in accessions of Centella asiatica. IJAHM 7:2643-2650

81. Gharagozloo M, Doroudchi M, Ghaderi A (2002) Effects of Citrus aurantifolia concentrated extract on the spontaneous proliferation of MDA-MB-453 and RPMI-8866 tumor cell lines. Phytomed 9(5):475-477. https://doi.org/10.1078/ 09447110260571751

82. Patil J, Jayaprakasha G, Chidambara Murthy K, Tichy S, Chetti M, Patil B (2009) Apoptosis-mediated proliferation inhibition of human colon cancer cells by volatile principles of Citrus aurantifolia. Food Chem 114(4):13511358. https://doi.org/10.1016/j.foodchem.2008.11.033

83. Block S, Stévigny C, De Pauw-Gillet MC, de Hoffmann E, Llabrès G, Adjakidjé $\checkmark$ (2002) Enttrachyloban-3ß-ol, a new cytotoxic diterpene from Croton zambesicus. Planta Med 68(7):647-649. https://doi.org/10.1055/s-2002-32903

84. Kimbi HK, Fagbenro-Beyioku AF (1996) Efficacy of Cymbopogon giganteus and Enantia chrantha against chloroquine resistant Plasmodium yoelii nigeriensis. East Afr Med J 73(10):636-637

85. Paulo A, Gomes ET, Steele J, Warhurst DC, Houghton PJ (2000) Antiplasmodial activity of Cryptolepis sanguinolenta alkaloids from leaves and roots. Planta Med 66(1):30-34. https://doi.org/10.1055/s-2000-11106

86. Kuttan R, Bhanumathy P, Nirmala K, George MC (1985) Potential anticancer activity of turmeric (Curcuma longa). Cancer Lett 29(2):197-202. https://doi. org/10.1016/0304-3835(85)90159-4

87. Huang MT, Lou YR, Ma W, Newmark HL, Reuhl KR, Conney AH (1994) Inhibitory effects of dietary curcumin on fore stomach, duodenal, and colon carcinogenesis in mice. Cancer Res 54(22):5841-5847

88. Ahm MR (2018) A review on medicinal plants with anticancer activity available in Bangladesh. Mod Appl Pharm Pharmacol 1(4):0516

89. Lee HZ, Hsu SL, Liu MC, Wu CH (2001) Effects and mechanisms of aloeemodin on cell death in human lung squamous cell carcinoma. Eur J Pharmacol 431(3):287-295. https://doi.org/10.1016/50014-2999(01)01467-4

90. Ahmad R, Srivastava AN, Khan MA (2016) Evaluation of in vitro anticancer activity of rhizome of Curcuma longa against human breast cancer and Vero cell lines. Int J Bot Stud 1(1):01-06

91. Arunee H, Kornkanok I, Nanteetip L, Daniel S (2014) Ethanolic extract from Derris scandens Benth mediates radiosensitzation via two distinct modes of cell death in human colon cancer HT-29 cells. Asian Pac J Cancer Prev 15(4): 1871-1877

92. Ito C, Matsui T, Miyabe K, Hasan CM, Rashid MA, Tokuda H, Itoigawa M (2020) Three isoflavones from Derris scandens (Roxb.) Benth and their cancer chemopreventive activity and in vitro antiproliferative effects. Phytochem 175:112376. https://doi.org/10.1016/.jphytochem.2020.112376

93. Kuete V, Fokou FW, Karaosmanoglu O, Beng VP, Sivas H (2017) Cytotoxicity of the methanol extracts of Elephantopus mollis, Kalanchoe crenata and 4 other Cameroonian medicinal plants towards human carcinoma cells. BMC Complement Altern Med 17(1):280. https://doi.org/10.1186/s12906-017-1 793-1

94. Musuyu MD, Fruth BI, Nzunzu Lami J, Mesia GK, Kambu OK, Tona GL (2012) In vitro antiprotozoal and cytotoxic activity of 33 ethonopharmacologically selected medicinal plants from Democratic Republic of Congo. J Ethnopharmacol 141(1):301-308. https://doi.org/10.1016/j.jep.2012.02.035

95. Salman TM, Adesokan AA (2008) Sperm quality of male rats treated with aqueous extract of Enantia chlorantha stem-bark. Afr J Biotechnol 7(7):865867

96. Barret Y, Sauvaire Y (1992) Fagaronine, a novel anti-leukemic alkaloid. Phyther Res 6(2):59-63. https://doi.org/10.1002/ptr.2650060202

97. Kassim OO, Copeland RL, Kenquele HM, Nekhai S, Ako-Nai KA, Kanaan YM (2015) Antiproliferative activities of Fagarax anthoxyloides and Pseudocedrela kotschyi against prostate cancer cell lines. Anticancer Res 35(3):1453-1458

98. Sharma JVC, Pitchaiah G, Satyavati D (2011b) In vitro anticancer activity of methanolic extract of roots of Glochidion zeylanicum (Gaertn.). Int J Res Pharmaceut Biomed Sci 2(2):760-764 
99. Sharma JVC, Shekar BC, Chakraborty R, Chanda H, Rao JV, Kumar HS (2011C) Anticancer activity of aqueous extract of roots of Glochidion zeylanicum (Gaertn.). J Pharm Biomed Sci 6(11):1-4

100. Fabisiak JP, Borisenko GG, Kagan VE (1993) Quantitative method of measuring phosphatidylserine externalization during apoptosis using electron paramagnetic resonance (EPR) spectroscopy and annexin conjugated iron. Methods Mol Biol 1105:613-621

101. Yue F, Tze-Chen H, Junqiao G (2004) Licochalcone- A: a novel flavonoid isolated from licorice root (Glycyrrhiza glabra), causes G2 and late-G1 arrests in androgen-independent PC-3 prostate cancer cells. Biochem Biophys Res Commun 322(1):263-270

102. Nazmi SA, Nourazarian A, Bahhaj R, Khakikhatibi F (2018) The anticancer effect of Arctium lappa and Glycyrrhiza glabra on HT-29 colon cancer and MCF-7 breast cancer cell lines. Crescent J Med Biol Sci 5(2):133-137

103. Aied MA, Rola A, Abdul MA (2013) Induction of caspase-9, biochemical assessment and morphological changes caused by apoptosis in cancer cells treated with goniothalamin extracted from Goniothalamus macrophyllus. Asian Pac J Cancer Prev 14(11):6273-6280

104. Wattanapiromsakul C, Wangsintaweekul B, Sangprapan P, Itharat A, Keawpradub N (2005) Goniothalamin, a cytotoxic compound, isolated from Goniothalamus macrophyllus (Blume) Hook. F. and Thomson var. macrophyllus Songklanakarin. J Sci Technol 27(2):479-487

105. Iwalewa EO, Naidoo V, Bagla V, Eloff JN (2009) Nitric oxide producing effect of six extracts from Harungana madagascariensis Lam. ex Poiret (Guttiferae) stem-bark. Afr J Pharm Pharmacol 3(1):14-21

106. Ochwang'I DO, Kimwele CN, Oduma JA, Gathumbi PK, Kiama SG, Efferth T (2018) Cytotoxic activity of medicinal plants of the Kakamega County (Kenya) against drug-sensitive and multidrug-resistant cancer cells. J Ethnopharmacol 215:233-240. https://doi.org/10.1016/j.jep.2018.01.004

107. Kouam SF, Ngadjui BT, Krohn K, Wafo P, Ajaz A, Choudhary MI (2005) Prenylatedanthronoid antioxidants from the stem-bark of Harungana madagascariensis. Phytochem 66(10):1174-1179. https://doi.org/10.1016/j. phytochem.2005.03.022

108. Androulakis XM, Muga SJ, Chen F, Koita Y, Toure B, Wargovich MJ (2006) Chemopreventive effects of Khaya senegalensis bark extract on human colorectal cancer. Anticancer Res 26(3B):2397-2405

109. Rabadeaux C, Vallette L, Sirdaarta J, Davis C, Sirdaarta J (2017) An examination of the antimicrobial and anticancer properties of Khaya senegalensis (Desr.) A. Juss. bark extracts. Pharm J 9(2):504-518. https://doi. org/10.5530/pj.2017.4.82

110. Olugbami JO, Damoiseaux R, France B, Gbadegesin MA, Stieg AZ, Sharma S (2017b) Atomic force microscopy correlates antimetastatic potentials of HepG2 cell line with its redox/energy status: Effects of curcumin and Khaya senegalensis. J Integr Med 15(3):214-230. https://doi.org/10.1016/S2095-4964 (17)60337-6

111. Zhang H, Wang X, Chen F, Androulakis XM, Wargovich MJ (2007) Anticancer activity of limonoid from Khaya senegalensis. Phyther Res 21(8):731-734. https://doi.org/10.1002/ptr.2148

112. Zhang $H$, Tan J, Vanderveer D, Wang X, Wargovich MJ, Chen F (2009) Khayanolides from African mahogany Khaya senegalensis (Meliaceae): a revision. Phytochem 70(2):294-299. https://doi.org/10.1016/j.phytochem.2 008.12 .004

113. Murakami A, Ohigashi H, Nozaki H, Tada T, Kaji M, Koshimizu K (1991) Possible inhibitor of tumor promotion and related polyphenol from Lophira alata, a medicinal plant in tropical West Africa. Agric Biol Chem 55(4):1151-1153

114. Murakami A, Tanaka S, Ohigashi H, Hirota M, Irie R, Takeda N (1992) Possible anti-tumor promoters: Bl- and tetraflavonoids from Lophira alata. Phytochem 31(8):2689-2693. https://doi.org/10.1016/0031-9422(92)83612-3

115. Ajiboye TO, Yakubu MT, Oladiji AT (2014) Cytotoxic antimutagenic, and antioxidant activities of methanolic extract and chalcone dimers (lophirones B and C) derived From Lophira alata (Van Tiegh Ex Keay) stem-bark. J Evid Based Compl Altern Med 19(1):20-30. https://doi.org/10.1177/2156587213 505112

116. Muanza DN, Euler KL, Williams L, Newman DJ (1995) Screening for antitumor andanti-HIV activities of nine medicinal plants from Zaire. Int $J$ Pharmacogn 33(2):98-106. https://doi.org/10.3109/13880209509055207

117. Prasad S, Kalra N, Shukla Y (2008) Induction of apoptosis by lupeol and mango extract in mouse prostate and LNCaP cells. Nutr Cancer 60(1):120 130. https://doi.org/10.1080/01635580701613772

118. Banerjee N, Kim H, Krenek K, Talcott ST, Mertens-Talcott SU (2015) Mango polyphenolics suppressed tumor growth in breast cancer xenografts in mice: role of the PI3K/AKT pathway and associated microRNAs. Nutr Res 35(8):744-751. https://doi.org/10.1016/j.nutres.2015.06.002

119. Khurana RK, Kaur R, Lohan S, Singh KK, Singh B (2016) Mangiferin: a promising anticancer bioactive. Pharm Pat Anal 5(3):169-181. https://doi. org/10.4155/ppa-2016-0003

120. Nemec MJ, Kim H, Marciante AB, Barnes RC, Hendrick ED, Bisson WH (2017) Polyphenolics from mango (Mangifera indica L.) suppresses breast cancer ductal carcinoma in situ proliferation through activation of AMPK pathway and suppression of mTOR in athymic nude mice. J Nutr Biochem 41:12-19. https://doi.org/10.1016/j.jnutbio.2016.11.005

121. Oke-Altuntas F, Kapche GDWF, Nantchouang Ouete JL, Demirtas I, Koc MB, Ngadjui BT (2016) Bioactivity evaluation of cudraxanthone I, neocyclomorusin and (9bh)-3b-acetoxylanosta-7,24-diene isolated from Milicia excelsa Welw. C. C. Berg (Moraceae). Med Chem Res 25(10):22502257. https://doi.org/10.1007/s00044-016-1670-3

122. Kuete V, Sandjo LP, Nantchouang JL, Fouotsa H, Wiench B, Efferth T (2014a) Cytotoxicity and modes of action of three naturally occurring xanthones (8hydroxycudraxanthone $\mathrm{G}$, morusignin I and cudraxanthone I) against sensitive and multidrug-resistant cancer cell lines. Phytomed 21(3):315-322. https://doi.org/10.1016/j.phymed.2013.08.018

123. Ouete NJL, Sandjo LP, Kapche DWFG, Liermann JC, Opatz T, Simo IK (2013) A new flavone from the roots of Milicia excelsa (Moraceae). Z Naturforsch C 68(7-8):259-263. https://doi.org/10.5560/ZNC.2013.68c0259

124. Suzuki M, Tung NH, Kwofie KD, Adegle R, Amoa-Bosompem M, Sakyiamah M (2015) New anti-trypanosomal active tetracyclic iridoid isolated from Morinda lucida Benth. Bioorg Med Chem Lett 25(15):3030-3033. https://doi. org/10.1016/j.bmcl.2015.05.003

125. Samje M, Metuge J, Mbah J, Nguesson B, Cho-ngwa F (2014) In vitro antiOnchocerca ochengi activities of extracts and chromatographic fractions of Craterispermum laurinum and Morinda lucida. BMC Complement Altern Med 14(1):325. https://doi.org/10.1186/1472-6882-14-325

126. Appiah-Opong R, Tuffour I, Annor GK, Blankson-Darku AD, Cramer P, KissiTwum AA (2016) Antiproliferative, antioxidant activities and apoptosis induction by Morinda lucidaand Taraxacum officinale in human HL-60 leukemia cells. J Glob Biosci 5(7):4281-4291

127. Durodola JI (1974) Anti-neoplastic property of crystalline compound extracted from Morinda lucida. Planta Med 26(3):208-211. https://doi.org/1 0.1055/s-0028-1099378

128. Adesogan EK (1979) Oruwacin, a new iridoid ferulate from Morinda lucida. Phytochem 18(1):175-176. https://doi.org/10.1016/S0031-9422(00)90940-3

129. Koumaglo K, Gbeassor M, Nikabu O, de Souza C, Werner W (1992) Effects of three compounds extracted from Morinda lucida on Plasmodium falciparum. Planta Med 58(6):533-534. https://doi.org/10.1055/s-2006-961543

130. Cimanga RK, Lutete GT, Mesia GK, Kambu OK, Bakana DP, Kalenda PDT (2006) Bioassay-guided isolation of antimalarial triterpenoid acids from the leaves of Morinda lucida. Pharm Biol 44(9):677-681. https://doi.org/10.1 080/13880200601009123

131. Kuete V, Wabo HK, Eyong KO, Feussi MT, Wiench B, Krusche B (2011) Anticancer activities of six selected natural compounds of some Cameroonian medicinal plants. PLoS One 6(8):e21762. https://doi.org/10.1371/journal.pone.0021762

132. Kuete V, Tankeo SB, Saeed ME, Wiench B, Tane P, Efferth T (2014b) Cytotoxicity and modes of action of five Cameroonian medicinal plants against multi-factorial drug resistance of tumor cells. J Ethnopharmacol 153(1):207-219. https://doi.org/10.1016/j.jep.2014.02.025

133. Tor-anyiin TA, Shaato R, Oluma HOA (2003) Ethnobotanical survey of antimalarial medicinal plants amongst the Tiv people of Nigeria. Int J Geogr Inf Syst 10(3):61-74

134. Eyong KO, Ketsemen HL, Ghansenyuy SY, Folefoc GN (2015) Chemical constituents, the stereochemistry of 3-hydroxy furonaphthoquinones from the root bark of Newbouldia laevis Seem (Bignoniaceae), and screening against Onchocerca ochengi parasites. Med Chem Res 24(3):965-969. https:// doi.org/10.1007/s00044-014-1173-z

135. Chang WC, Hsieh CH, Hsiao MW, Lin WC, Hung YC, Ye JC (2010) Caffeic acid induces apoptosis in human cervical cancer cells through the mitochondrial pathway. Taiwan J Obstet Gynecol 49(4):419-424. https://doi.org/10.1016/S1 028-4559(10)60092-7

136. Njoku CJ, Zeng L, Asuzu IU, Oberlies NH, McLaughlin JL (2003) Oleanolic acid, a bioactive component of the leaves of Ocimum gratissimum (Lamiaceae). Int J Pharmacogn 35(2):134-137

137. Nangia-Makker P, Raz T, Tait L, Shekhar MP, Li H, Balan V (2013) Ocimum gratissimum retards breast cancer growth and progression and is a natural 
inhibitor of matrix metalloproteases. Cancer Biol Ther 14(5):417-427. https:// doi.org/10.4161/cbt.23762

138. Chen YY, Chiang SY, Lin JG, Ma YS, Liao CL, Weng SW, Lai TY, Chung JG (2010) Emodin, aloe-emodin and rhein inhibit migration and invasion in human tongue cancer SCC-4 cells through the inhibition of gene expression of matrix metalloproteinase-9. Int J Oncol 36(5):1113-1120. https://doi.org/10.3892/ijo_00000593

139. Lin CC, Chao PY, Shen CY, Shu JJ, Yen SK, Huang CY (2014) Novel target genes responsive to apoptotic activity by Ocimum gratissimum in human osteosarcoma cells. Am J Clin Med 42(3):743-767. https://doi.org/10.1142/ S0192415X14500487

140. Obianime AW, Aprioku JS, Esomonu CTO (2010) Antifertility effects of aqueous crude extract of Ocimum gratissimum L. leaves in male mice. J Med Plant Res 4(9):809-816

141. Kang JH, Song KH, Woo JK (2011) Ginsenoside Rp1 from Panax ginseng exhibits anti-cancer activity by down-regulation of the IGF-1R/Akt pathway in breast cancer cells. Plant Foods Hum Nutr 66(3):298-305. https://doi.org/1 0.1007/s11130-011-0242-4

142. Kim SJ, Kim AK (2015) Anti-breast cancer activity of fine black ginseng (Panax ginseng Meyer) and ginsenoside Rg5. J Ginseng Res 39(2):125-134. https://doi.org/10.1016/j.jgr.2014.09.003

143. Tang Y, Jaganath IB, Sekaran SD (2010) Phyllanthus spp. induces selective growth inhibition of PC-3 and MeWo human cancer cells through modulation of cell cycle and induction of apoptosis. PLoS One 5(9):e12644. https://doi.org/10.1371/journal.pone.0012644

144. Tang YQ, Jaganath IB, Manikam R, Sekaran SD (2015) Phyllanthus spp. exerts anti-angiogenic and anti-metastatic effects through inhibition on matrix metalloproteinase enzymes. Nutr Cancer 67(5):783-795. https://doi.org/10.1 080/01635581.2015.1040518

145. Nguyen VT, Sakoff JA, Scarlett CJ (2017) Physicochemical properties, antioxidant and cytotoxic activities of crude extracts and fractions from Phyllanthus amarus. Med 4(2):42

146. Waraporn Y, Athikom S, Roongtawan S (2013) Suppression of human fibrosarcoma cell metastasis by Phyllanthus emblica extract in vitro. Asian Pac J Cancer Prev 14(11):6863-6867

147. Manosroi A, Jantrawut P, Akazawa H, Akihisa T, Manosroi J (2010) Biological activities of phenolic compounds isolated from galls of Terminalia chebula Retz. (Combretaceae). Nat Prod Res 24(20):1915-1926. https://doi.org/10.1 080/14786419.2010.488631

148. Galano A, Marquez MF, Pérez-González A (2014) Ellagic acid: an unusually versatile protector against oxidative stress. Chem Res Toxicol 27(5):904-918. https://doi.org/10.1021/tx500065y

149. Singh M, Jha A, Kumar A, Hettiarachchy N, Rai AK, Sharma D (2014b) Influence of the solvents on the extraction of major phenolic compounds (punicalagin, ellagic acid and gallic acid) and their antioxidant activities in pomegranate aril. J Food Sci 51(9):2070-2077

150. Sumalatha D (2013) Antioxidant and antitumor activity of Phyllanthus emblica in colon cancer cell lines. Int J Curr Microbiol App Sci 2(5):189-195

151. Mahata S, Pandey A, Shukla S, Tyagi A, Husain SA, Das BC, Bharti AC (2013) Anticancer activity of Phyllanthus emblica Linn. (Indian Gooseberry): Inhibition of transcription factor AP-1 and HPV gene expression in cervical cancer cells. Nutr Cancer 65(1):88-97. https://doi.org/10.1080/01635581.2013.785008

152. Kumar MH, Ramesh C (2014) Antimutagenic activity of root extract of Picrorhiza kurroa using Ames test in both dose dependent cytotoxic assay and mutagenicity study. J Pharmacogn Phytochem 2(6):48-52

153. Soni D, Grover A (2019) "Picrosides" from Picrorhiza kurroa as potential anticarcinogenic agents. Biomed Pharmacother 109:1680-1687. https://doi. org/10.1016/j.biopha.2018.11.048

154. Mallick MN, Singh M, Parveen R, Khan W, Ahmad S, Najm MZ, Husain SA (2015) HPTLC analysis of bioactivity-guided anticancer enriched fraction of hydroalcoholic extract of Picrorhiza kurroa. Biomed Res Int 513875:18

155. Ryu NH, Park KR, Kim SM, Yun HM, Nam D, Lee SG (2012) A hexane fraction of guava leaves (Psidium guajava L.) induces anticancer activity by suppressing AKT/mammalian target of rapamycin/ribosomal p70 S6 kinase in human prostate cancer cells. J Med Food 15(3):231-241. https://doi.org/1 0.1089/jmf.2011.1701

156. Corrêa MG, Couto JS, Teodoro AJ (2016) Anti-cancer properties of Psidium quajava - a mini-review. Asian Pac Organ Cancer Prev 17(9):4199-4204

157. Syed DN, Chamcheu JC, Adhami VM, Mukhtar H (2013) Pomegranate extracts and cancer prevention: molecular and cellular activities. Anti Cancer Agents Med Chem 13(8):1149-1161. https://doi.org/10.2174/1871520611313080003
158. Bemis DL, Capodice JL, Gorroochurn P, Katz AE, Buttyan R (2006) Antiprostate cancer activity of ab-carboline alkaloid enriched extract from Rauwolfia vomitoria. Int J Oncol 29(5):1065-1073

159. Yu J, Ma Y, Drisko J, Chen Q (2013) Antitumor activities of Rauwolfia vomitoria extract and potentiation of carboplatin effects against ovarian cancer. Curr Ther Res Clin Exp 75:8-14. https://doi.org/10.1016/.j.curtheres.2013.04.001

160. Yu J, Chen Q (2014) Anti-tumor activities of Rauwolfia vomitoria extract and potentiation of gemcitabine effects against pancreatic cancer. Integr Cancer Ther 13(3):217-225. https://doi.org/10.1177/1534735414532010

161. Lembe DM, Koloko BL, Bend EF, Domkam J, Oundoum PC, Njila MN (2014) Fertility enhancing effects of aqueous extract of Rauvolfia vomitoria on reproductive functions of male rats. J Exp Integr Med 4(1):43-49. https://doi. org/10.5455/jeim.200913.or.090

162. Ahsan M, Islam SK, Gray Al, Stimson WH (2003) Cytotoxic diterpenes from scopariadulcis. J Nat Prod 66(7):958-961. https://doi.org/10.1021/np020356

163. Wu WH, Chen TY, Lu RW, Chen ST, Chang CC (2012) Benzoxazinoids from Scoparia dulcis (sweet broom weed) with antiproliferative activity against the DU-145 human prostate cancer cell line. Phytochem 83:110-115. https://doi.org/10.1016/j.phytochem.2012.07.022

164. Fuentes RG, Toume K, Arai MA, Sadhu SK, Ahmed F, Ishibashi M (2015) Scopadulciol isolated from Scoparia dulcis, induces b-catenin degradation and overcomes tumor necrosis factor-related apoptosis ligand resistance in AGS human gastric adenocarcinoma cells. J Nat Prod 4:864-872

165. Hyun JW, Kun-Young P, Chung-Ho R, Won HL, Byung TC, Gi YK, Yeong-Min P, Yung HC (2006) $\beta$-Lapachone, a quinone isolated from Tabebuia avellanedae, induces apoptosis in HepG2 Hepatoma cell line through induction of Bax and activation of caspase. J Med Food 9(2):161-168

166. El-khamissi HAZ, Saad ZH, Rozan HE (2019) Phytochemicals screening, antioxidant and anticancer activities of garlic (Allium sativum) extracts. J Agric Chem Biotech 10(4):79-82

167. Sertel S, Eichhorn T, Plinkert PK, Efferth T (2011) Cytotoxicity of Thymus vulgaris essential oil towards human oral cavity squamous cell carcinoma. Anticancer Res 31(1):81-87

168. Jagetia GC, Rao SK (2006) Evaluation of the antineoplastic activity of guduchi (Tinospora cordifolia) in Ehrlich ascites carcinoma bearing mice. Biol Pharm Bull 29(3):460-466. https://doi.org/10.1248/bpb.29.460

169. Ahmad R, Srivastava AN, Khan MA (2015) Evaluation of in vitro anticancer activity of stem of Tinospora cordifolia against human breast cancer and Vero cell lines. J Med Plants Stud 3(4):33-37

170. Deepa B, Babaji HV, Hosmani JV, Alamir AWH, Mushtaq S, Raj AT, Patil S (2019) Effect of Tinospora cordifolia-derived phytocomponents on cancer: a systematic review. Appl Sci 9(23):5147. https://doi.org/10.3390/app9235147

171. Kuroda M, Yokosuka A, Kobayashi R, Jitsuno M, Kando H, Nosaka K (2007) Sesquiterpenoids and flavonoids from the aerial parts of Tithonia diversifolia and their cytotoxic activity. Chem Pharm Bull 55(8):1240-1244. https://doi. org/10.1248/cpb.55.1240

172. Lee MY, Liao MH, Tsai YN, Chiu KH, Wen HC (2011) Identification and antihuman glioblastoma activity of tagitinin C from Tithonia diversifolia methanolic extract. J Agric Food Chem 59(6):2347-2355. https://doi.org/10.1 021/jf105003n

173. Gu JQ, Gills JJ, Park EJ, Mata-Greenwood E, Hawthorne ME, Axelrod F (2002) Sesquiterpenoids from Tithonia diversifolia with potential cancer chemopreventive activity. J Nat Prod 65(4):532-536. https://doi.org/10.1021/ np010545m

174. Liao MH, Lin WC, Wen HC, Pu HF (2011) Tithonia diversifolia and its main active component tagitinin $\mathrm{C}$ induce survivin inhibition and G2/M arrest in human malignant glioblastoma cells. Fitoterapia 82(3):331-341. https://doi. org/10.1016/j.fitote.2010.11.002

175. Monday T, Ojokuku SA, Ogunyemi IO, Odesanmi OS (2015) Toxicological studies of herbal anti-tumor extract (Uvaria chamae) in monosodium glutamate and tamoxifen treated Sprague-Dawley rat. Int Res J Biol Sci 4(6):62-68

176. Luo X, Oyugi DA, Lin C, Izevbigie EB, Lee KS (2010) Isolation and characterization of the antibreast carcinoma cell growth components of Vernonia amygdalina extracts. Exp Biol Med 235(12):1472-1478. https://doi. org/10.1258/ebm.2010.010124

177. Izevbigie EB (2003) Discovery of water-soluble anticancer agents (edotides) from a vegetable found in Benin City, Nigeria. Exp Biol Med 228(3):293-298. https://doi.org/10.1177/153537020322800308

178. Gresham L, Ross J, Izevbigie EB (2008) Vernonia amygdalina: anticancer activity, authentication and adulteration detection. Int J Environ Res Public Health 5(5):342-348. https://doi.org/10.3390/ijerph5050342 
179. Fang SD, Wang LK, Hecht SM (1993) Inhibitors of DNA topoisomerase I isolated from the roots of Zanthoxylum nitidum. J Organomet Chem 58(19): 5025-5027. https://doi.org/10.1021/jo00071a001

180. Venkateswaralu G, Swarupa Rani T, Vani M, Vineela PAJ (2015) In vitro anticancer activity of petroleum ether extracts of Cynodon dactylon. J Pharmacogn Phytochem 4(1):164-168

181. Wang CF, Fan L, Tian M (2015) Cytotoxicity of benzophenanthridine alkaloids from the roots of Zanthoxylum nitidum (Roxb.) DC. var. fastuosum How ex Huang. Nat Prod Res 29(14):1380-1383. https://doi.org/10.1080/14 786419.2014.1002090

182. Liu CM, Kao CL, Tseng YT, Lo YC, Chen CY (2017) Ginger phytochemicals inhibit cell growth and modulates drug resistance factors in docetaxel resistant prostate cancer cell. Mol 22(9):1477. https://doi.org/10.3390/ molecules22091477

183. Hu R, Zhou P, Peng YB, Xu X, Ma J, Liu Q (2012) 6-Shogaol induces apoptosis in human hepatocellular carcinoma cells and exhibits anti-tumor activity in vivo through endoplasmic reticulum stress. PLoS One 7(6):e39664. https://doi.org/10.1371/journal.pone.0039664

184. Wu JJ, Omar HA, Lee YR, Teng YN, Chen PS, Chen YC (2015) 6-Shogaol induces cell cycle arrest and apoptosis in human hepatoma cells through pleiotropic mechanisms. Eur J Pharmacol 762:449-458. https://doi.org/10.1 016/j.ejphar.2015.06.032

185. Martin ACBM, Fuzer AM, Becceneri AB, da Silva JA, Tomasin R, Denoyer D (2017) [10]-Gingerol induces apoptosis and inhibits metastatic dissemination of triple negative breast cancer in vivo. Oncotarget 8(42):72260-72271. https://doi.org/10.18632/oncotarget.20139

186. Li Z, Wang Y, Gao M, Cui W, Zeng M, Cheng Y (2018) Nine new gingerols from the rhizoma of Zingiber officinale and their cytotoxic activities. Mol 23(2):315. https://doi.org/10.3390/molecules23020315

187. Shak S, Palmer G, Baehner FL, Millward C, Watson D, Sledge GW (2009) Molecular characterization of male breast cancer by standardized quantitative RT-PCR analysis: a large genomic study of 1,447 male breast cancers. J Clin Oncol 27(15):549-549. https://doi.org/10.1200/jco.2009.27.15_suppl.549

188. Malik A, Afaq S, Shahid M, Akhtar K, Assiri A (2011) Influence of ellagic acid on prostate cancer cell proliferation: a caspase dependent pathway. Asian Pac J Trop Med 4(7):550-555. https://doi.org/10.1016/S1995-7645(11)60144-2

189. Singh S, Singh PP, Roberts LR, Sanchez W (2014a) Chemopreventive strategies in hepatocellular carcinoma. Nat Rev Gastroenterol Hepatol 11(1): 45-54. https://doi.org/10.1038/nrgastro.2013.143

190. Soomro S, Chidrawar VR, Imran M, Alshammari HO (2019) Immunomodulating, anti-bacterial and anti-cancer potential of Za'atar (Thymus vulgaris) and its combination with essential oil (Olive and Balsam Oil). Int J Pharm Sci 10(8):3721-3726

191. Azmi AS, Bhat SH, Hanif S, Hadi SM (2006) Plant polyphenols mobilize endogenous copper in human peripheral lymphocytes leading to oxidative DNA breakage: a putative mechanism for anticancer properties. FEBS Lett 580(2):533-538. https://doi.org/10.1016/j.febslet.2005.12.059

192. Siriwantanmetanon N, Fiebich BL, Efferth T, Prieto JM, Heinrich M (2010) Traditionally used Thai medicinal plants: In vitro anti-inflammatory, anticancer and antioxidant activities. J Ethnopharmacol 130(2):196-207. https://doi.org/10.1016/j.jep.2010.04.036

193. Heo BG, Park YJ, Park YS, Bae JH, Cho JY, Park K, Jastrzebski Z, Gorinstein S (2014) Anticancer and antioxidant effects of extracts from different parts of indigo plant. Ind Crop Prod 56:9-16. https://doi.org/10.1016/j.indcrop.2014. 02.023

194. Gupta SC, Tyagi AK, Deshmukh-Taskar P, Hinojosa M, Prasad S, Aggarwal BB (2014) Downregulation of tumor necrosis factor and other proinflammatory biomarkers by polyphenols. Arch Biochem Biophys 559:91-99. https://doi. org/10.1016/j.abb.2014.06.006

195. Cao J, Xia X, Chen X, Xiao J, Wang Q (2013) Characterization of flavonoids from Dryopteris erythrosora and evaluation of their antioxidant, anticancer and acetylcholinesterase inhibition activities. Food Chem Toxicol 51:242250. https://doi.org/10.1016/j.fct.2012.09.039

196. Kumar S, Pathania AS, Saxena AK, Vishwakarma RA, Ali A, Bhunshan S (2013) The anticancer potential of flavonoids isolated from the stem-bark of Erythrina suberosa through induction of apoptosis and inhibition of STAT signaling pathway in human leukaemia HL-60 cells. Chemico-Biol Interact 205(2):128-137. https://doi.org/10.1016/j.cbi.2013.06.020

197. Xia X, Cao J, Zheng Y, Wang Q, Xiao J (2014) Flavonoid concentrations and bioactivity of flavonoid extracts from 19 species of ferns from China. Ind Crop Prod 58:91-98. https://doi.org/10.1016/j.indcrop.2014.04.005
198. Greenwell M, Rahman PKSM (2015) Medicinal plants: their use in anticancer treatment. Int J Pharm Sci 6(10):4103-4112

199. Sun Y, Xun K, Wang Y, Chen X (2009) A systematic review of the anticancer properties of berberine, a natural product from Chinese herbs. Anti-Cancer Drugs 20(9):757-769. https://doi.org/10.1097/CAD.0b013e328330d95b

200. Diogo CV, Machado NG, Barbosa IA, Serafim TL, Burgeiro A, Oliveira PJ (2011) Berberine as a promising safe anti-cancer agent - is there a role for mitochondria? Curr Drug Targets 12(6):850-859. https://doi.org/10.2174/13 8945011795528930

201. Tan W, Lu J, Huang M (2011) Anti-cancer natural products isolated from Chinese medicinal herbs. Chin Med 6(1):27. https://doi.org/10.1186/1749-8546-6-27

202. Eom KS, Kim HJ, So HS, Park R, Kim TY (2010) Berberine-induced apoptosis in human glioblastoma T98G cells is mediated by endoplasmic reticulum stress accompanying reactive oxygen species and mitochondrial dysfunction. Biol Pharm Bull 33(10):1644-1649. https://doi.org/10.1248/bpb.33.1644

203. Burgeiro A, Gajate C, Dakir EH, Villa-Pulgarın JA, Oliveira PJ, Mollinedo F (2011) Involvement of mitochondrial and B-RAF/ERK signaling pathways in berberine-induced apoptosis in human melanoma cells. Anti-Cancer Drugs 22(6):507-518. https://doi.org/10.1097/CAD.0b013e32834438f6

204. Wang N, Feng Y, Zhu M (2010) Berberine induces autophagic cell death and mitochondrial apoptosis in liver cancer cells: the cellular mechanism. J Cell Biochem 111(6):1426-1436. https://doi.org/10.1002/jcb.22869

205. Tang F, Wang D, Duan C (2009) Berberine inhibits metastasis of nasopharyngeal carcinoma 5-8F cells by targeting rhokinase-mediated ezrin phosphorylation at threonine 567. J Biol Chem 284(40):27456-27466. https://doi.org/10.1074/jbc.M109.033795

206. Ho YT, Yang JS, Li TC (2009) Berberine suppresses in vitro migration and invasion of human SCC-4 tonguesquamous cancer cells through the inhibitions of FAK, IKK,NF-KB, U-PA and MMP-2 and -9. Cancer Lett 279(2): 155-162. https://doi.org/10.1016/j.canlet.2009.01.033

207. Jie S, Li H, Tian Y (2011) Berberine inhibits angiogenic potential of Hep G2 cell line through VEGF down-regulation in vitro. J Gastroenterol Hepatol 26(1):179-185. https://doi.org/10.1111/j.1440-1746.2010.06389.x

208. Hamsa TP, Kuttan G (2012) Antiangiogenic activity of berberine is mediated through the downregulation of hypoxia-inducible factor-1, VEGF, and proinflammatory mediators. Drug Chem Toxicol 35(1):57-70. https://doi. org/10.3109/01480545.2011.589437

209. Debiton E, Madelmont JC, Legault J, Barthomeuf C (2003) Sanguinarineinduced apoptosis is associated with a nearly and severe cellular glutathione depletion. Cancer Chemother Pharmacol 51(6):474-482. https:// doi.org/10.1007/s00280-003-0609-9

210. Chang MC, Chan CP, Wang YJ (2007) Induction of necrosis and apoptosis to $\mathrm{KB}$ cancer cells by sanguinarineis associated with reactive oxygen species production and mitochondrial membrane depolarization. Toxicol Appl Pharmacol 218(2):143-151. https://doi.org/10.1016/j.taap.2006.10.025

211. Kim S, Lee TJ, Leem J, Kyeong SC, Park JW, Taeg KK (2008) Sanguinarineinduced apoptosis: generation of ROS, down-regulation of BCl-2, c-FLIP, and synergy with TRAIL. J Cell Biochem 104(3):895-907. https://doi.org/10.1002/ jcb.21672

212. Jang BC, Park JG, Song DK (2009) Sanguinarine induces apoptosis in A549 human lung cancer cells primarily viacellular glutathione depletion. Toxicol in Vitro 23(2):281-287. https://doi.org/10.1016/j.tiv.2008.12.013

213. Bachran C, Bachran S, Sutherland M, Bachran D, Fuchs H (2008) Saponins in tumor therapy. Mini-Rev Med Chem 8(6):575-584. https://doi.org/10.2174/13 8955708784534445

214. Yıldırım I, Kutlu T (2015) Anti-cancer agents: saponin and tannin. Int J Biol Chem 9(6):332-340. https://doi.org/10.3923/ijbc.2015.332.340

215. Park JH, Kwak JH, Khoo JH, Park SH, Kim DU (2010) Cytotoxic effects of triterpenoid saponins from Androsace umbellate against multidrug resistance (MDR) and non-MDR cells. Arch Pharm Res 33(8):1175-1180. https://doi. org/10.1007/s12272-010-0807-z

216. Tin MM, Cho CH, Chan K, James AE, Ko JK (2007) Astragalus saponins induce growth inhibition and apoptosis in human colon cancer cells and tumor xenograft. Carcinog 28(6):1347-1355. https://doi.org/10.1093/carcin/bgl238

217. Tong QY, He Y, Zhao QB, Qing Y, Huang W, Wu XH (2012) Cytotoxicity and apoptosis-inducing effect of steroidal saponins from Dioscorea zingiberensis wright against cancer cells. Steroids 77(12):1219-1227. https://doi.org/10.101 6/j.steroids.2012.04.019

218. Man S, Gao W, Zhang Y, Huang L, Liu C (2010) Chemical study and medical application of saponins as anti-cancer agents. Fitoterapia 81(7):703-714. https://doi.org/10.1016/j.fitote.2010.06.004 
219. Yogeeswari P, Sriram D (2005) Betulinic acid and its derivatives: a review on their biological properties. Curr Med Chem 12(6):657-666. https://doi.org/1 $0.2174 / 0929867053202214$

220. Lu M, Xia L, Hua H, Jing Y (2008) Acetyl-keto-beta-boswellic acid induces apoptosis through a death receptor 5-mediated pathway in prostate cancer cells. Cancer Res 68(4):1180-1186. https://doi.org/10.1158/0008-5472.CAN07-2978

221. Amico V, Barresi V, Condorelli D, Spatafora C, Tringali C (2006) Antiproliferative terpenoids from almond hulls (Prunus dulcis): identification and structure-activity relationships. J Agric Food Chem 54(3):810-814. https://doi.org/10.1021/jf052812q

222. Rzeski W, Stepulak A, Szymanski M, Sifringer M, Kaczor J, Wejksza K (2006) Betulinic acid decreases expression of bcl-2 and cyclin D1, inhibits proliferation, migration and induces apoptosis in cancer cells. Naunyn Schmiedeberg's Arch Pharmacol 374(1):11-20. https://doi.org/10.1007/s0021 0-006-0090-1

223. Kessler JH, Mullauer FB, de Roo GM, Medema JP (2007) Broad in vitro efficacy of plant-derived betulinic acid against cell lines derived from the most prevalent human cancer types. Cancer Lett 251(1):132-145. https://doi. org/10.1016/j.canlet.2006.11.003

224. Li H, He N, Li X, Zhou L, Zhao M, Jiang H (2013) Oleanolic acid inhibits proliferation and induces apoptosis in NB4 cells by targeting PML/RARalpha. Oncol Lett 6(4):885-890. https://doi.org/10.3892/ol.2013.1497

225. Wang X, Bai H, Zhang X, Liu J, Cao P, Liao N (2013) Inhibitory effect of oleanolic acid on hepatocellular carcinoma via ERK-p53-mediated cell cycle arrest and mitochondrial-dependent apoptosis. Carcinog 34(6):1323-1330. https://doi.org/10.1093/carcin/bgt058

226. Lee YS, Jin DQ, Kwon EJ, Park SH, Lee ES, Jeong TC (2002) Asiatic acid, a triterpene, induces apoptosis through intracellular $\mathrm{Ca}^{2+}$ release and enhanced expression of p53 in HepG2 human hepatoma cells. Cancer Lett 186(1):83-91. https://doi.org/10.1016/S0304-3835(02)00260-4

227. Chang UM, Li CH, Lin LI, Huang CP, Kan LS, Lin SB (2006) Ganoderiol F, a ganoderma triterpene, induces senescence in hepatoma HepG2 cells. Life Sci 79(12):1129-1139. https://doi.org/10.1016/j.lfs.2006.03.027

228. Es-Saady D, Simon A, Jayat-Vignoles C, Chulia AJ, Delage C (1996) MCF-7 cell cycle arrested at G1 through ursolic acid, and increased reduction of tetrazolium salts. Anticancer Res 16(1):481-486

229. Huang W, Huang J, Zhang D, Zhang R, Liao Z (2003) Study on anti-invasive effect and apoptosis induction of pentacyclic triterpenoid in human lung cancer cells. CJLC 6(4):254-257

230. Yu LB, Wang J, Ma BZ, Sun WZ (2010) Inhibitive effect of ursolic acid on the invasion and metastasis of ovarian carcinoma cells HO-8910PM. Sichuan Da Xue Xue Bao Yi Xue Ban 41(6):986-988

231. Lin J, Chen Y, Wei L, Hong Z, Sferra TJ, Peng J (2013) Ursolic acid inhibits colorectal cancer angiogenesis through suppression of multiple signaling pathways. Int J Oncol 43(5):1666-1674. https://doi.org/10.3892/ijo.2013.2101

232. Zhang W, Men X, Lei $P$ (2014) Review on anti-tumor effect of triterpene acid compounds. J Can Res Ther 10(5):14-19

233. Larrosa M, Tomas-Barberan FA, Espin JC (2006) The dietary hydrolysable tannin punicalagin releases ellagic acid that induces apoptosis in human colon adenocarcinoma CaCo-2 cells by using the mitochondrial pathway. J Nutr Biochem 17(9):611-625. https://doi.org/10.1016/j.jnutbio.2005.09.004

234. Jia L, Jin H, Zhou J, Chen L, Lu Y, Ming Y, Yu Y (2013) A potential anti-tumor herbal medicine, Corilagin, inhibits ovarian cancer cell growth through blocking the TGF- $\beta$ signaling pathways. BMC Complement Altern Med 13(1):33. https://doi.org/10.1186/1472-6882-13-33

235. Chen KS, Hsiao YC, Kuo DY, Chou MC, Chu SC, Hsieh YS, Lin TL (2009) Tannic acid-induced apoptosis and -enhanced sensitivity to arsenic trioxide in human leukemia HL-60 cells. Leuk Res 33(2):297-307. https://doi.org/10.1 016/j.leukres.2008.08.006

236. Kuo PL, Lin TC, Lin CC (2002) The antiproliferative activity of aloe-emodin is through p53-dependent and p21-dependent apoptotic pathway in human hepatoma cell lines. Life Sci 71(16):1879-1892. https://doi.org/10.1016/ S0024-3205(02)01900-8

237. Guo JM, Xiao BX, Liu Q, Zhang S, Liu DH, Gong ZH (2007) Anti-cancer effect of aloe-emodin on cervical cancer cells involves G2/M arrest and induction of differentiation. Acta Pharmacol Sin 28(12):1991-1995. https://doi.org/1 0.1111/j.1745-7254.2007.00707.x

238. Xiao B, Guo J, Liu D, Zhang S (2007) Aloe-emodin induces in vitro G2/M arrest and alkaline phosphatase activation in human oral cancer KB cells. Oral Oncol 43(9):905-910. https://doi.org/10.1016/j.oraloncology.2006.11.002
239. Guo J, Xiao B, Liu Q, Gong Z, Le Y (2008) Suppression of C-myc expression associates with anti-proliferation of aloe-emodin on gastric cancer cells. Cancer Investig 26(4):369-374. https://doi.org/10.1080/07357900701788130

240. Chiu TH, Lai WW, Hsia TC, Yang JS, Lai TY, Wu PP, Ma CY, Yeh CC, Ho CC, Lu HF, Wood WG, Chung JG (2009) Aloe-emodin induces cell death through Sphase arrest and caspase-dependent pathways in human tongue squamous cancer SCC-4 cells. Anticancer Res 29(11):4503-4511

241. Lee HZ, Lin CJ, Yang WH, Leung WC, Chang SP (2006) Aloeemodin-induced DNA damage through generation of reactive oxygen species in human lung carcinoma cells. Cancer Lett 239(1):55-63. https://doi.org/10.1016/j.ca nlet.2005.07.036

242. Yeh FT, Wu CH, Lee HZ (2003) Signaling pathway for aloe-emodin-induced apoptosis in human H460 lung non-small carcinoma cell. Int J Cancer 106(1):26-33. https://doi.org/10.1002/ijc.11185

243. Pecere T, Sarinella F, Salata C, Gatto B, Bet A, Dalla VF, Diaspro A, Carli M, Palumbo M, Palu G (2003) Involvement of p53 in specific antineuroectodermal tumor activity of aloe-emodin. Int J Cancer 106(6):836847. https://doi.org/10.1002/ijc.11312

244. Tabolacci C, Lentini A, Mattioli P, Provenzano B, Oliverio S, Carlomosti F, Beninati S (2010) Antitumor properties of aloe-emodin and induction of transglutaminase 2 activity in B16-F10 melanoma cells. Life Sci 87(9-10):316324. https://doi.org/10.1016/j.lfs.2010.07.003

245. Suboj P, Babykutty S, Valiyaparambil GDR, Nair RS, Srinivas P, Gopala S (2012) Aloe emodin inhibits colon cancer cell migration/angiogenesis by downregulating MMP-2/9, RhoB and VEGF via reduced DNA binding activity of NF-kappaB. Eur J Pharm Sci 45(5):581-591. https://doi.org/10.1016/j.ejps.2 011.12 .012

246. Cornblatt BS, Ye L, Dinkova-Kostova AT, Erb M, Fahey JW, Singh K, Chen MA Stierer T, Garrett-Mayer E, Argani P, Davidson NE, Talalay P, Kensler TW, Visvanathan K (2007) Preclinical and clinical evaluation of sulforaphane for chemoprevention in the breast. Carcinog 28(7):1485-1490. https://doi.org/1 0.1093/carcin/bgm049

247. Amin A, Gali-Muhtasib H, Ocker M, Schneider-Stock R (2009) Overview of major classes of plant- derived anticancer drugs. Int J Biomed Sci 5(1):1-11

248. Phillipson JD (1999) Medicinal plants. J Biol Educ 31(2):109

249. Unnati S, Ripal S, Sanjeev A, Niyati A (2013) Novel anticancer agents from plant sources. Chin J Nat Med 11(1):0016-0023

250. Pezzuto JM (1997) Plant-derived anticancer agents. Biochem Pharmacol 53(2):121-133. https://doi.org/10.1016/S0006-2952(96)00654-5

251. Heiss E, Herhaus C, Klimo K, Bartsch H, Gerhäuser C (2001) Nuclear Factor kB is a molecular target for sulforaphane-mediated anti-inflammatory mechanisms. J Biol Chem 276(34):32008-32015. https://doi.org/10.1074/jbc. M104794200

252. Jordan MA, Wilson $L$ (2004) Microtubules as a target for anticancer drugs. Nat Rev Cancer 4(4):253-265. https://doi.org/10.1038/nrc1317

253. Cragg GM, Newman DJ (2005) Plants as a source of anti-cancer agents. J Enthnopharmacol 100(1-2):72-79. https://doi.org/10.1016/j.jep.2005.05.011

254. Son IH, Chung IM, Lee SI, Yang HD, Moon HI (2007) Pomiferin, histone deacetylase inhibitor isolated from the fruits of Maclura pomifera. Bioorg Med Chem Lett 17(17):4753-4755. https://doi.org/10.1016/j.bmcl.2007.06.060

\section{Publisher's Note}

Springer Nature remains neutral with regard to jurisdictional claims in published maps and institutional affiliations. 